\title{
Dynamics of nitrogen oxides and ozone above and within a mixed hardwood forest in northern Michigan
}

\author{
B. Seok ${ }^{1,2}$, D. Helmig ${ }^{1}$, L. Ganzeveld ${ }^{3}$, M. W. Williams ${ }^{1,4}$, and C. S. Vogel $^{5}$ \\ ${ }^{1}$ Institute of Arctic and Alpine Research, University of Colorado, Boulder, CO, USA \\ ${ }^{2}$ Department of Atmospheric and Oceanic Sciences, University of Colorado, Boulder, CO, USA \\ ${ }^{3}$ Department of Environmental Sciences, Wageningen University and Research Centre, Wageningen, the Netherlands \\ ${ }^{4}$ Department of Geography, University of Colorado, Boulder, CO, USA \\ ${ }^{5}$ University of Michigan Biological Station, University of Michigan, Pellston, MI, USA
}

Correspondence to: B. Seok (seok@colorado.edu) and D. Helmig (detlev.helmig@colorado.edu)

\begin{abstract}
The dynamic behavior of nitrogen oxides $\left(\mathrm{NO}_{\mathrm{x}}=\mathrm{NO}+\mathrm{NO}_{2}\right)$ and ozone $\left(\mathrm{O}_{3}\right)$ above and within the canopy at the University of Michigan Biological Station AmeriFlux (UMBS Flux) site was investigated by continuous multi-height vertical gradient measurements during the summer and the fall of 2008. A daily maximum in nitric oxide (NO) mixing ratios was consistently observed during the morning hours between 06:00 and 09:00 EST above the canopy. Daily NO maxima ranged between 0.1 and 2 ppbv (with a median of $0.3 \mathrm{ppbv}$ ), which were 2 to 20 times above the atmospheric background. The sources and causes of the morning $\mathrm{NO}$ maximum were evaluated using $\mathrm{NO}_{\mathrm{x}}$ and $\mathrm{O}_{3}$ measurements and synoptic and micrometeorological data. Numerical simulations with a multi-layer canopy-exchange model were done to further support this analysis. The observations indicated that the morning NO maximum was caused by the photolysis of $\mathrm{NO}_{2}$ from non-local air masses, which were transported into the canopy from aloft during the morning breakup of the nocturnal boundary layer. The analysis of simulated process tendencies indicated that the downward turbulent transport of $\mathrm{NO}_{\mathrm{x}}$ into the canopy compensates for the removal of $\mathrm{NO}_{\mathrm{x}}$ through chemistry and dry deposition. The sensitivity of $\mathrm{NO}_{\mathrm{x}}$ and $\mathrm{O}_{3}$ concentrations to soil and foliage $\mathrm{NO}_{\mathrm{x}}$ emissions was also assessed with the model. Uncertainties associated with the emissions of $\mathrm{NO}_{\mathrm{x}}$ from the soil or from leaf-surface nitrate photolysis did not explain the observed diurnal behavior in $\mathrm{NO}_{\mathrm{x}}$ (and $\mathrm{O}_{3}$ ) and, in particular, the morning peak in $\mathrm{NO}_{\mathrm{x}}$ mixing ratios. However, a $\sim 30 \%$ increase in early morning $\mathrm{NO}_{\mathrm{x}}$ and $\mathrm{NO}$ peak mixing ratios was simulated when a foliage exchange $\mathrm{NO}_{2}$ compensation point was considered. This increase suggests the
\end{abstract}

potential importance of leaf-level, bidirectional exchange of $\mathrm{NO}_{2}$ in understanding the observed temporal variability in $\mathrm{NO}_{\mathrm{x}}$ at UMBS.

\section{Introduction}

Nitrogen oxides $\left(\mathrm{NO}_{\mathrm{x}}=\mathrm{NO}+\mathrm{NO}_{2}\right)$, which originate from combustion, lightning, and soil emissions, play a critical role in regulating the photochemical production of ozone $\left(\mathrm{O}_{3}\right)$ in the troposphere (Crutzen, 1970; Jacob, 2000; Crutzen and Lelieveld, 2001; Hauglustaine et al., 2001). Excessive deposition of $\mathrm{NO}_{\mathrm{x}}$, which contributes to the total nitrogen input on ecosystems, and exposure of vegetation to toxic levels of $\mathrm{O}_{3}$ can cause foliage damage; $\mathrm{NO}_{\mathrm{x}}$ deposition is linked to acidification and eutrophication of forests (Mosier et al., 2001; Grunhage et al., 2002).

$\mathrm{NO}_{\mathrm{x}}$ and $\mathrm{O}_{3}$ concentrations (and fluxes) have been measured in forest ecosystems to quantify $\mathrm{NO}_{\mathrm{x}}$ and $\mathrm{O}_{3}$ dry deposition in relatively polluted conditions (e.g., CASTNET; US Environmental Protection Agency, 2009). Other measurements of $\mathrm{NO}_{\mathrm{x}}$ and $\mathrm{O}_{3}$ were done to study the role of canopy interactions between biogenic emissions, dry deposition, chemistry, and turbulence in determining bidirectional exchange of $\mathrm{NO}_{\mathrm{x}}$ between more pristine forests and the overlying atmosphere (e.g. Bakwin et al., 1990, 1994; Carroll and Thompson, 1995; Munger et al., 1996; Rummel et al., 2002). The University of Michigan Biological Station (UMBS) is one of those sites with a history of $\mathrm{NO}_{\mathrm{x}}$ and $\mathrm{O}_{3}$ measurements since 1997 from the Program for Research on Oxidants: PHotochemistry, Emissions 
and Transport (PROPHET; Carroll et al., 2001). At the PROPHET site, Thornberry et al. (2001) observed a periodic mixing ratio maximum of $\mathrm{NO}_{\mathrm{x}}$ in the morning hours above the forest canopy. A similar behavior was also observed at other forest sites (e.g. Parrish et al., 1993; Munger et al., 1996; Andreae et al., 2002; Farmer and Cohen, 2008). Alaghmand et al. (2011) concluded that to understand the diurnal behavior in $\mathrm{NO}_{\mathrm{x}}$ mixing ratios at sites such as UMBS, the combined role of (nocturnal) mixing and transport processes needs to be considered, and this would require the coupling of canopy and boundary layer turbulence models.

In this study, we used the combined analysis of below, within, and above canopy observations and model simulations (1) to investigate the cause for the observed morning peak in $\mathrm{NO}_{\mathrm{x}}$ mixing ratios differentiating between the role of local versus distant sources of $\mathrm{NO}_{\mathrm{x}}$ and (2) to assess the sensitivity of in-canopy $\mathrm{NO}_{\mathrm{x}}\left(\right.$ and $\left.\mathrm{O}_{3}\right)$ to potentially relevant in-canopy sources and sinks under atmospheric conditions encountered at UMBS. Results are based on an analysis of a five-month data set of $\mathrm{NO}_{\mathrm{x}}, \mathrm{NO}$, and $\mathrm{O}_{3}$ vertical mixing ratio profiles, which were measured above and within the canopy of the UMBS forest in the summer and the fall of 2008. Simulations with a multi-layer canopy-boundary layer exchange model further supported the analysis.

\section{Measurements}

\subsection{Site description}

This study was conducted from 19 July to 21 November 2008 at the AmeriFlux site in the UMBS domain $\left(45.5932^{\circ} \mathrm{N}\right.$, $84.7130^{\circ} \mathrm{W}$; Schmid et al., 2003). This site is located in an area rather distant from major anthropogenic sources although it is quite often ( $\sim 40 \%$ of the time) affected by advection of polluted air masses. The nearest metropolitan areas (population >200 000) are Detroit, Michigan, $\sim 350 \mathrm{~km}$ to the southeast; Milwaukee, Wisconsin, $\sim 350 \mathrm{~km}$ to the southwest; and Chicago, Illinois, $\sim 450 \mathrm{~km}$ also to the southwest.

The UMBS forest falls in the transition zone between mixed hardwood and boreal forests with a mean annual (from 1979 to 2009) temperature of $6.7^{\circ} \mathrm{C}$ and rainfall of $803.4 \mathrm{~mm}$ (Vande Kopple, 2011). The pre-settlement forest, dominated by white pine (Pinus strobus), red pine (Pinus resinosa), and hemlock (Tsuga canadensis), was cut around 1880. The area was disturbed repeatedly by fire until 1923. Today, within a $1 \mathrm{~km}$ radius of the AmeriFlux tower, the forest is composed mainly of bigtooth aspen (Populus grandidentata) and trembling aspen (Populus tremuloides), but there is also significant representation of maple (Acer rubrum), red oak (Quercus rubra), birch (Betula papyrifera), and beech (Fagus grandifolia). In patches, there is a dense understory of young white pine, up to $\sim 6 \mathrm{~m}$ high. The understory layer near the forest floor is dominated by bracken fern (Pteridium aquil- inum) and saplings of red maple, red oak, beech, and white pine (Gough et al., 2007).

The forest at UMBS has two distinctive layers: a crown layer and an understory layer (Fig. 1). The mean canopy height around the AmeriFlux tower was $\sim 22 \mathrm{~m}$ (Schmid et al., 2003). The average seasonal maximum (from 1999 to 2009) of the cumulative single-sided leaf area index (LAI, $\mathrm{m}^{2} \mathrm{~m}^{-2}$ ) was 3.5 . The average seasonal LAI began to decrease in early-October, and it reached its average seasonal minimum of 1.5 by November.

\subsection{Instrumentation}

A UV absorbance monitor (DASIBI 1003-AH) was used to measure the mixing ratio of $\mathrm{O}_{3}$ through the canopy. Before installing the DASIBI at the site, a 5-point calibration was conducted against a TEI 49C monitor (Thermo Environmental Instruments, Inc. (TEI), Franklin, MA, USA), which served as the transfer standard for the calibration. Brodin et al. (2010) describe the calibration of this transfer standard in detail. The calibration of the DASIBI resulted a $1 \mathrm{ppbv}$ offset with a $3 \%$ slope correction. The $\mathrm{O}_{3}$ data from the DASIBI were corrected for this difference. The detection limit of the DASIBI was 1 ppbv.

The mixing ratio of $\mathrm{NO}_{\mathrm{x}}$ was determined with a chemiluminescence analyzer (TEI 42C-TL). This instrument follows the Federal Reference method as designated by the US EPA, which is also the most prevalent method of measuring ambient air $\mathrm{NO}_{\mathrm{x}}$ (Demerjian, 2000). The TEI 42C-TL has two channels. The first channel measures nitric oxide (NO) via $\mathrm{NO}+\mathrm{O}_{3}$ chemiluminescence. The second channel measures nitrogen dioxide $\left(\mathrm{NO}_{2}\right)$ by redirecting air through a heated $\left(325^{\circ} \mathrm{C}\right)$ molybdenum converter, which causes $\mathrm{NO}_{2}$ - and other oxidized nitrogen compounds - to convert to NO. The $\mathrm{NO}_{2}$ mixing ratio is then determined by subtracting NO, measured in the first channel. There are several interferences in this $\mathrm{NO}_{2}$ measurement scheme (Steinbacher et al., 2007). The error in the $\mathrm{NO}_{2}$ measurement increases with rising amounts of interfering gases such as nitrous acid (HONO), peroxyacetyl nitrate (PAN), and alkyl nitrates that contribute to the $\mathrm{NO}_{2}$-mode signal. However, in urban environments, $\mathrm{NO}_{\mathrm{x}}$ typically constitutes the largest fraction of oxidized nitrogen compounds (Spicer, 1982; Steinbacher et al., 2007); hence, $\mathrm{NO}_{2}$ mixing ratios obtained with the TEI $42 \mathrm{C}$-TL will represent a reasonable estimate if the site is influenced by anthropogenic sources. Furthermore, a recent intercomparison of $\mathrm{NO}_{\mathrm{x}}$ measurement techniques showed that $\mathrm{NO}$ and $\mathrm{NO}_{2}$ measured with a molybdenum oxide (MoO) converter instrument yielded values that differed from instruments using other techniques (e.g., photolytical converter) only by 2 and $3 \%$, respectively, for ambient air measurements at a semi-rural site in Germany (Gilge et al., 2013). Before the deployment of the TEI 42C-TL analyzer in the summer of 2008, the instrument was sent to TEI for preventive maintenance. TEI reported the instrument to have a $\mathrm{NO}_{2}$ 


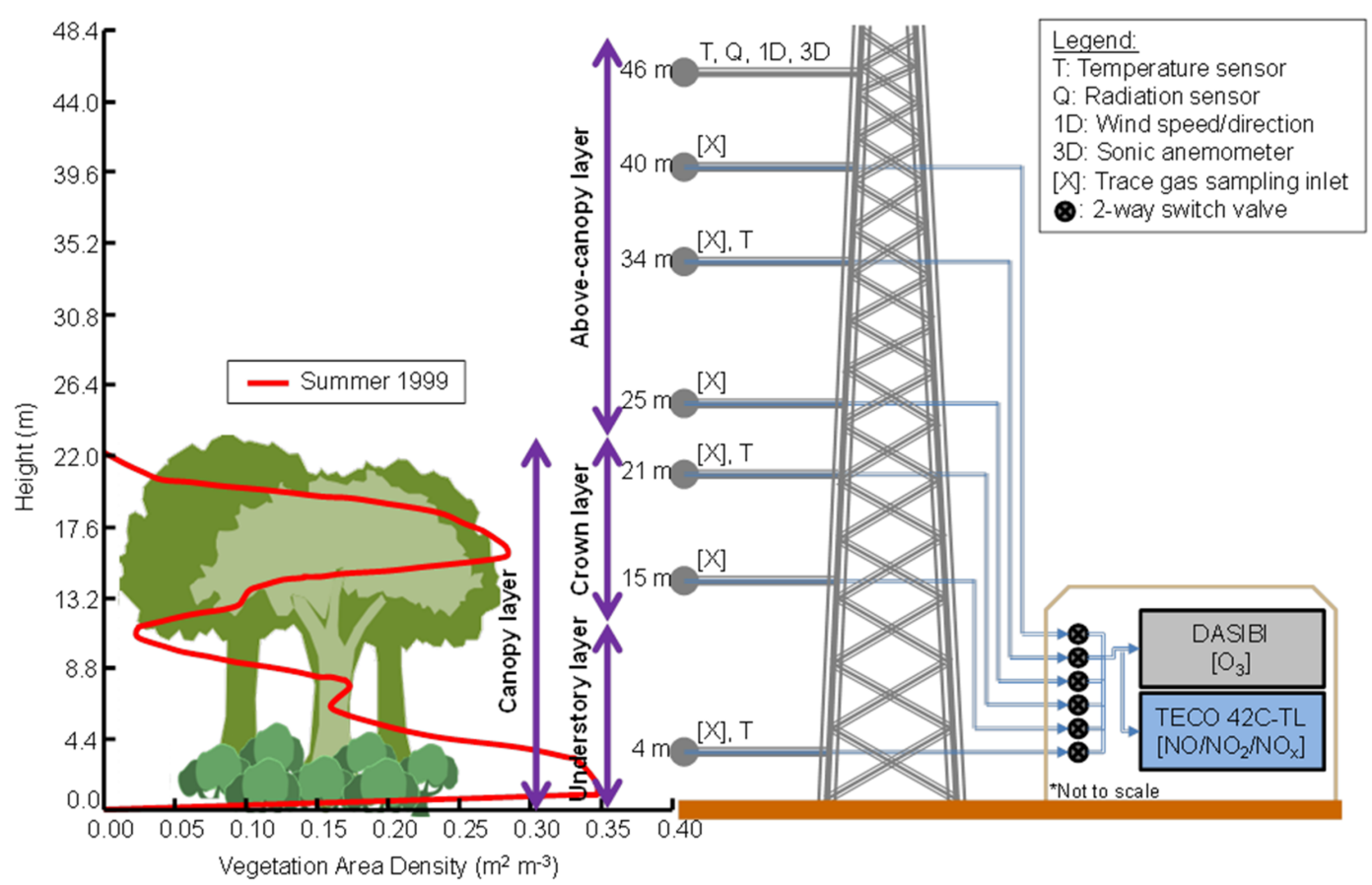

Fig. 1. The forest architecture as vegetation area density profile at UMBS in the summer of 1999, modified from Fig. 2 a of Schmid et al. (2003), and a cartoon depiction of the AmeriFlux tower with sensor locations drawn to scale but gas analyzers and housing unit not drawn to scale.

conversion efficiency of $99.9 \%$ after servicing it. Ultra-zero air (Airgas Great Lakes, Inc., Royal Oak, MI, USA) was used to establish baseline conditions and for dilution of a NISTtraceable 1 ppmv NO gas standard (Scott-Marrin, Inc., Riverside, CA) to multiple calibration gas levels between 0.5 and $10 \mathrm{ppbv}$. After propagating the uncertainties of the mass flow controllers and the NO gas standard, we estimated the uncertainty in the NO determination to be $\sim 5 \%$. The signal noise was $0.05 \mathrm{ppbv}$, which resulted in a detection limit of $\sim 0.1 \mathrm{ppbv}$. The detection limit was determined by taking three times the standard deviation of the blank (the ultra-zero air).

Note that from hereon, we will use $\mathrm{NO}_{2, \mathrm{MO}}$ and $\mathrm{NO}_{\mathrm{x}, \mathrm{MO}}$ to indicate that the $\mathrm{NO}_{2}$ and $\mathrm{NO}_{\mathrm{x}}$ results in our study are those measured with a $\mathrm{MoO}$ converter instrument.

\subsection{Sampling}

Vertical mixing ratio profiles of $\mathrm{NO}_{\mathrm{x}, \mathrm{MO}}$ and $\mathrm{O}_{3}$ were measured from the AmeriFlux tower at 4, 15, 21, 25, 34, and $40 \mathrm{~m}$ above the ground (Fig. 1). Sampling through each inlet was done sequentially from the $40 \mathrm{~m}$ height down to the $4 \mathrm{~m}$ height. The sampling inlet at a particular height was selected through a manifold constructed of an array of six two-way solenoid valves with polytetrafluoroethylene (PTFE) body seals (Norgren USA, Littleton, CO, USA). Each sampling interval was $5 \mathrm{~min}$ long with gas mixing ratios being de- termined in this flow every minute. A complete cycle took $30 \mathrm{~min}$, thus there were 48 cycles per day.

Perfluoroalkoxy (PFA) inlet funnels with $1 \mathrm{~mm}$ grids (Savillex Co., Minnetonka, MN, USA) were used to prevent large debris from being drawn into the sampling line. Single stage $47 \mathrm{~mm}$ PFA filter clamps (Savillex Co.) with $5 \mathrm{~mm}$ PTFE membrane filter (Millipore Co., Bellerica, MA, USA) were placed upstream of the instrument inlet to prevent fine particles from interfering with $\mathrm{NO}_{\mathrm{x}, \mathrm{MO}}$ and $\mathrm{O}_{3}$ measurements.

All sampling lines, valves, and filters were conditioned for three days with a flow of $2 \mathrm{~L} \mathrm{~min}^{-1}$ of air containing $200 \mathrm{ppbv}$ of $\mathrm{O}_{3}$ prior to installation. This was done to minimize the loss of $\mathrm{O}_{3}$ in the manifold during subsequent field sampling. Six equal-length $61 \mathrm{~m}$-long PFA Teflon ${ }^{\circledR}$ tubes with outer diameter of $6.4 \mathrm{~mm}$ and inner diameter of $3.6 \mathrm{~mm}$ (Parker Hannifin, Cleveland, OH, USA) were used as sampling lines. The excess tubing for the sampling inlets closer to the instruments were coiled and kept in the same housing unit as the instruments.

The flow rate through the DASIBI was $1.8 \mathrm{~L} \mathrm{~min}^{-1}$, and the TEI 42C-TL flow rate was $1.2 \mathrm{~L} \mathrm{~min}^{-1}$. Therefore, the total flow rate through each sampling line was $3 \mathrm{~L} \mathrm{~min}^{-1}$. The theoretical transport time of air samples from the inlet to the gas analyzers was calculated (using tubing dimensions, manifold volume, and purge rate) to be $15 \mathrm{~s}$. 


\subsubsection{Bias in the sampling lines}

All the sampling inlets were intercompared by bringing them to the $15 \mathrm{~m}$ height of the tower. This was done to determine the potential measurement bias, as there are inherent differences in the sampling lines. Mixing ratios of $\mathrm{NO}$ and $\mathrm{O}_{3}$ and line pressure were monitored through each line over a 2-day period. The sampling lines varied $<0.1 \mathrm{ppbv}$ in $\mathrm{NO},<1 \mathrm{ppbv}$ in $\mathrm{O}_{3}$, and $<2 \mathrm{kPa}$ in pressure against each other.

\subsubsection{Correcting for the loss of NO in the sampling lines}

NO undergoes rapid oxidation through its reaction with $\mathrm{O}_{3}$ and other free radicals, e.g., hydroperoxy $\left(\mathrm{HO}_{2}\right)$ and alkylperoxy $\left(\mathrm{RO}_{2}\right)$, in the atmosphere. Therefore, it is necessary to correct for the loss of NO during the transport in the sampling line to the analyzer. Since ambient air $\mathrm{HO}_{2}$ and $\mathrm{RO}_{2}$ levels are two to three orders of magnitude smaller than NO (Fuchs et al., 2008), it was assumed they would not affect the sampled NO mixing ratios. The loss of NO due to oxidation by $\mathrm{O}_{3}$ alone was considered in the correction. In the absence of light, $\mathrm{NO}$ is oxidized to $\mathrm{NO}_{2}$ by

$\mathrm{NO}+\mathrm{O}_{3} \stackrel{k}{\rightarrow} \mathrm{NO}_{2}+\mathrm{O}_{2}$,

where $k$ is the reaction rate constant $(k=1.4 \times$ $10^{-12} e^{-1310 / T} \quad\left[\mathrm{~cm}^{3}\right.$ molecules $\left.{ }^{-1} \mathrm{~s}^{-1}\right]$, for $T$ between 195 and $308 \mathrm{~K}$; Atkinson et al., 2004).

The reaction rate constants were calculated using ambient temperature recorded when the air sample was collected. The conversion rate of $\mathrm{NO}$ was then determined from (R1) using the $\mathrm{O}_{3}$ mixing ratio measured at any given moment from the same inlet. From this conversion rate, the percentage of NO lost after $15 \mathrm{~s}$, which was the residence time of the air sample in the tube, was calculated. Up to $32 \%$ of the NO was converted to $\mathrm{NO}_{2}$ by $\mathrm{O}_{3}$, depending on the air sample temperature, $\mathrm{O}_{3}$ mixing ratio, and line pressure. The NO mixing ratio was corrected for this loss. $\mathrm{NO}_{2, \mathrm{MO}}$ mixing ratios were recalculated accordingly by subtracting the correct NO mixing ratio from the $42 \mathrm{C}$-TL's output of the $\mathrm{NO}_{\mathrm{x}, \mathrm{MO}}$ mixing ratio.

\subsection{Ancillary data}

Meteorological instrumentation on the AmeriFlux tower provided the ancillary data used in the analyses (see Schmid et al., 2003, for information about the instruments). Wind speed, wind direction, turbulence, and incoming solar radiation were measured from the $46 \mathrm{~m}$ height of the tower (Fig. 1). Turbulence data $\left(u^{\prime}\right.$ and $\left.w^{\prime}\right)$, measured from the 3-D sonic anemometer, were used to calculate the friction velocity $\left(u_{*}=-\left\langle u^{\prime} w^{\prime}\right\rangle^{0.5}\left[\mathrm{~m} \mathrm{~s}^{-1}\right]\right)$ above the canopy. Temperatures below and above the canopy were measured from temperature sensors at $4,21,34$, and $46 \mathrm{~m}$ on the tower (Fig. 1). From the temperature data, temperature lapse rates $\left(\gamma=\left(T_{z_{1}}-T_{z_{2}}\right) /\left(z_{1}-z_{2}\right)\left[{ }^{\circ} \mathrm{Cm}^{-1}\right]\right)$ through the canopy (4 and $21 \mathrm{~m}$ ) and above the canopy (21 and $34 \mathrm{~m}$ ) were calculated to diagnose atmospheric stability.

\section{Single column canopy model}

\subsection{Model description and initialization parameters}

A multi-layer atmospheric-biosphere exchange model implemented in a single column chemistry-climate model (SCM; Ganzeveld et al., 2002a, 2006, 2008) was used to evaluate the dynamical behavior of $\mathrm{NO}_{\mathrm{x}}$ and $\mathrm{O}_{3}$ mixing ratios observed above and within the forest canopy. In contrast to most site-scale atmosphere-biosphere exchange models, the SCM does not use observed meteorological parameters to simulate exchanges. Instead, the SCM determines the dynamic behavior of the system (including the hydrological cycle, boundary layer dynamics, convection, and cloud formation) from initial vertical profiles and surface properties online and reanalysis of weather data (see below).

The atmosphere-biosphere trace gas exchange calculations in the SCM included dry deposition, biogenic emissions, in-canopy chemical transformations, turbulence, and the extinction of radiation within the canopy. All processes were simulated explicitly as a function of the SCM's meteorological, hydrological, and atmospheric chemistry parameters as well as the canopy structure distinguishing a crown layer and an understory layer. Stomatal and non-stomatal removal in the dry deposition of $\mathrm{NO}_{\mathrm{x}}$ and $\mathrm{O}_{3}$ (and other gases) is considered in the SCM. The stomatal conductance is calculated from in-canopy radiation profiles and soil moisture status, whereas the non-stomatal removal is a function of cuticular and soil uptake resistances (Ganzeveld and Lelieveld, 1995). The soil biogenic NO emission flux is normally calculated by the SCM according to a modified implementation of the Yienger and Levy (1995) algorithm. However in this study, a range of constant soil $\mathrm{NO}$ emission fluxes was applied in a sensitivity analysis with the reference soil NO emission flux being selected based on the observed emission flux of NO from the soil at the site (see Sect. 5.2.1). The model also considers the potentially relevant contribution to canopy $\mathrm{NO}_{\mathrm{x}}$ by photolysis of nitrate that has accumulated on leaf surfaces (e.g. Zhou et al., 2003, 2011). The emissions of biogenic volatile organic compounds (BVOCs; i.e. isoprene and monoterpenes) are calculated in the SCM according to Guenther et al. (1995) or alternatively with the Model of Emission of Gases and Aerosols from Nature (MEGAN; Guenther et al., 2006). In this study, we applied the Guenther et al. (1995) implementation based on observed emission factors at the leaf-scale reported for this site (Ortega et al., 2007, see Table 1). This results in a simulated canopy isoprene emission flux comparable to that reported by Pressely et al. (2005). Note that the canopy does not act as a uniform source of soil or foliar emissions in our model, but instead, 
Table 1. Model input parameters for the UMBS AmeriFlux site.

\begin{tabular}{llll}
\hline Parameter & Unit & Value & Reference \\
\hline Canopy height & $\mathrm{m}$ & 22 & Schmid et al. (2003) \\
Surface roughness & $\mathrm{m}$ & 2.2 & Schmid et al. (2003) \\
LAI & $\mathrm{m}^{2} \mathrm{~m}^{-2}$ & 3.5 & This study \\
Albedo & - & 0.15 & Hollinger et al. (2010) \\
Isoprene emis. factor & $\mu \mathrm{g} \mathrm{Cg}^{-1} \mathrm{~h}^{-1}$ & 50 & Ortega et al. (2007) \\
Monoterpene emis. factor & $\mu \mathrm{g} \mathrm{Cg}^{-1} \mathrm{~h}^{-1}$ & 0.7 & Ortega et al. (2007) \\
Soil NO emis. rate & $\mathrm{ng} \mathrm{N} \mathrm{m}^{-2} \mathrm{~s}^{-1}$ & 0.07 & Nave et al. (2011) \\
Leaf nitrate conc. & $\mathrm{nmol} \mathrm{cm}^{-2}$ & 0.83 & Zhou et al. (2011) \\
O 3 soil uptake rate & $\mathrm{cm} \mathrm{s}^{-1}$ & 0.25 & Ganzeveld and Lelieveld (1995) \\
Synoptic meteorology & - & ECMWF & Ganzeveld et al. (2006) \\
Chem. initialization & - & $\mathrm{NO}_{\mathrm{x}}$ and $\mathrm{O}_{3}$ & This study \\
& & mixing ratios & \\
\hline
\end{tabular}

the source and sink strengths change with time and height inside the canopy.

The atmosphere-biosphere exchange simulations also require initialization of a selection of biogeophysical parameters, e.g., LAI, canopy height, surface roughness, and the vertical distribution of biomass (expressed by the leaf area density profile). Values used for these parameters to simulate conditions found at UMBS are also provided in Table 1 (and in Fig. 1 for the leaf area density profile).

A key feature of the SCM for site-scale evaluation is the consideration of advection and synoptic weather systems. To consider changes in weather, reanalysis data from the European Centre for Medium range Weather Forecast (ECMWF) were applied, which typically results in realistic representation of the site meteorology (Ganzeveld et al., 2006). For the representation of advection of long-lived trace gases, the simulated boundary layer mixing ratios above the canopy (but not those inside and below the canopy) of $\mathrm{NO}_{\mathrm{x}}$ and $\mathrm{O}_{3}$ in the SCM were "nudged" (forced) towards observed mixing ratios. In this study, our tracer nudging used a relaxation time of $300 \mathrm{~s}$ (for a model time step of $60 \mathrm{~s}$ ) to capture some of the rapid fluctuations in the observed mixing ratios while avoiding numerical instabilities.

\subsection{Model run scenarios}

Three sets of model runs were performed to evaluate the role of the "biogenic" versus the "anthropogenic" exchange regime in explaining the observed diurnal variability in $\mathrm{NO}_{\mathrm{x}}$ and $\mathrm{O}_{3}$ at UMBS. All the model runs simulated the month of August observations. Two different model runs focused on the sensitivity to soil $\mathrm{NO}$ emissions and on foliage $\mathrm{NO}_{\mathrm{x}}$ emissions by varying the emission rates by $0,1,10$, and 25 times the default values (see Table 1). One other additional simulation focused on the role of leaf-scale bidirectional $\mathrm{NO}_{\mathrm{x}}$ exchanges.
Table 2. UMBS 1979-2010 climatological data for months when measurements were taken.

\begin{tabular}{lrr|rr|rr}
\hline Month & \multicolumn{3}{c|}{ Temperature $\left({ }^{\circ} \mathrm{C}\right)$} & \multicolumn{2}{c}{ Precipitation (mm) } \\
\cline { 2 - 7 } & \multicolumn{2}{c|}{$1979-2010$} & \multicolumn{2}{|c|}{2008} & $1979-2010$ & 2008 \\
\cline { 2 - 7 } & Avg. Min & Avg. Max & Min & Max & $\begin{array}{r}\text { Avg. Total } \\
( \pm 1 \text { std. dev. })\end{array}$ & Total \\
& & & & & & \\
\hline Jul & 15.1 & 25.7 & 15 & 25.6 & $700( \pm 150)$ & 600 \\
Aug & 14.6 & 24.4 & 14.4 & 25.6 & $850( \pm 154)$ & 500 \\
Sep & 10.3 & 19.8 & 10.6 & 20 & $880( \pm 166)$ & 630 \\
Oct & 4.3 & 12.2 & 4.4 & 12.2 & $920( \pm 178)$ & 310 \\
Nov & -0.71 & 5.3 & 0.0 & 5.0 & $730( \pm 123)$ & 680 \\
\hline
\end{tabular}

\section{Results and discussion of observations}

\subsection{Meteorological data}

We focus our analysis on observations for the months of August and November. These two months were selected since August represented a state of the forest canopy during a period of highest mean seasonal LAI. In contrast, November was chosen as a period after leaf abscission when the forest canopy was at its lowest mean seasonal LAI.

Weather conditions between July and November in 2008 were typical for UMBS. Temperature variations at UMBS were within the ranges of the temperature normal from 1979 to 2010 , but total precipitation during this period was lower than the average climatic conditions. This deviation in total precipitation was not considered anomalous or extreme as they were within 1-standard deviation from the mean (Table 2).

Figure 2 shows the seasonal decline in the daily maximum of incoming solar radiation from July to November (i.e. daytime maxima of $\sim 700 \mathrm{Wm}^{-2}$ and $\sim 250 \mathrm{~W} \mathrm{~m}^{-2}$, respectively). Similarly, the daily temperature amplitude above canopy decreased from $\sim 11^{\circ} \mathrm{C}$ in July to $\sim 4^{\circ} \mathrm{C}$ in November. The daily amplitude in friction velocity tracks the pattern of the incoming solar 

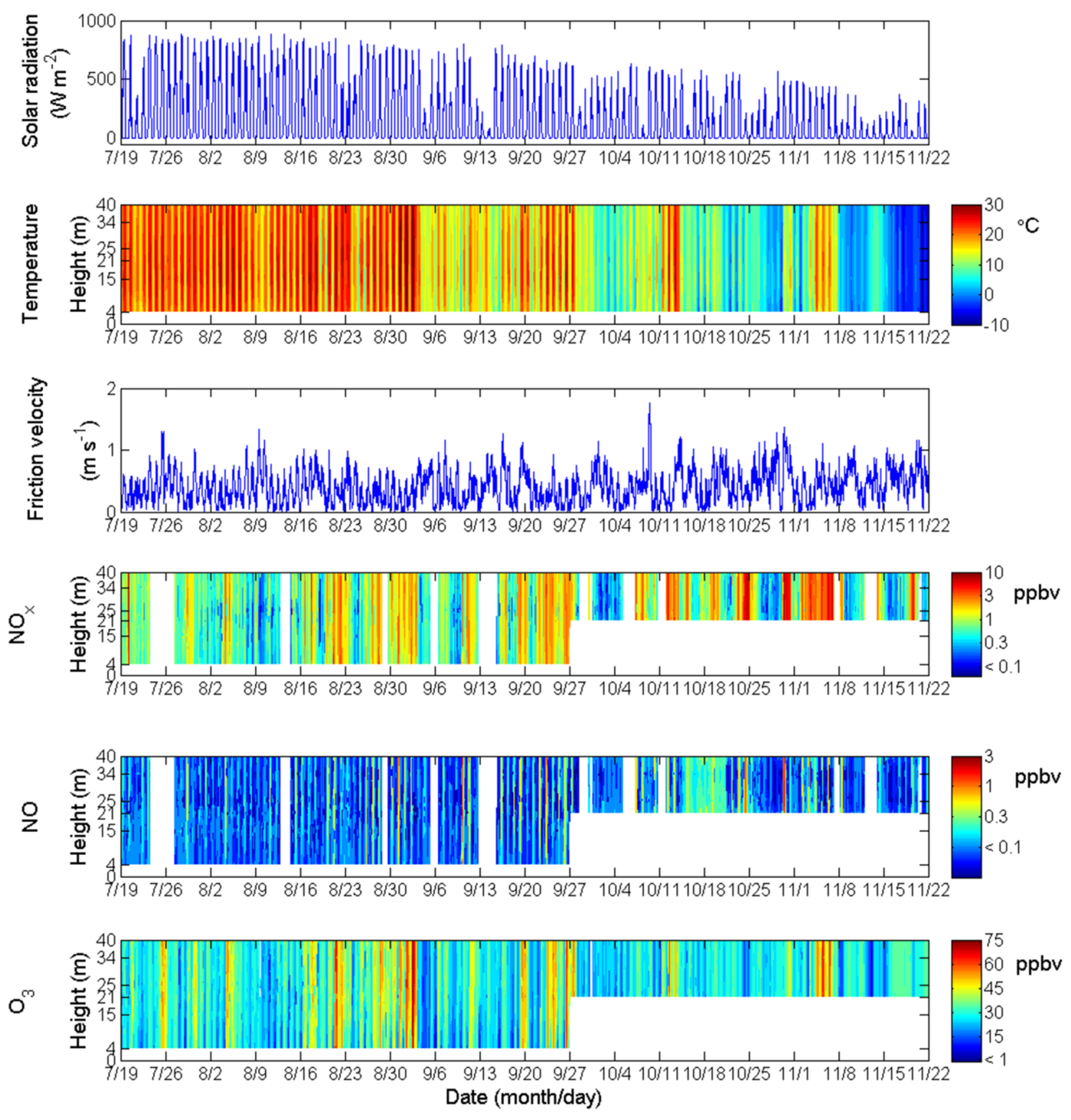

Fig. 2. The evolution of solar radiation, temperature profile, friction velocity, and the mixing ratio profiles of $\mathrm{NO}_{\mathrm{x}, \mathrm{MO}}, \mathrm{NO}$, and $\mathrm{O}_{3}$ at the UMBS AmeriFlux site from 19 July to 21 November 2008. Missing data were due to taking the instruments offline for calibrations and repairs and due to running intercomparison tests of the sampling inlets. Gaps in the chemical data below the canopy from 27 September onward were due to failures in the 4 and $15 \mathrm{~m}$ switching valves.

radiation with decreasing absolute amplitude (difference between daily minimum and daily maximum) over the fivemonth period with daytime maxima $>1 \mathrm{~m} \mathrm{~s}^{-1}$, indicating intense daytime turbulent exchange and minimum nocturnal friction velocities $\sim 0.2 \mathrm{~m} \mathrm{~s}^{-1}$ reflecting the suppressed nighttime mixing conditions.

The monthly average daily cycle of solar radiation, temperature lapse rate, and friction velocity for August and November are shown in Fig. 3. Sunrise shifted from 06:00 to 07:30 EST between August and November. Sunset changed from 19:00EST in August to 17:30EST in November. The diurnal pattern of the observed above-canopy friction velocity closely followed the solar radiation cycle. Nocturnal fric- tion velocities averaged $0.2 \mathrm{~m} \mathrm{~s}^{-1}$ in August and $0.4 \mathrm{~m} \mathrm{~s}^{-1}$ in November, implying inefficient turbulent mixing in the above canopy layer at night. Apparent increases in mixing (or friction velocity) were observed $>30 \mathrm{~min}$ after sunrise.

Since no direct turbulence measurements inside the canopy were available, temperature lapse rates from the vertical temperature profile measurements (see Sect. 2.4) were used, in addition to friction velocity, as a proxy for the efficiency of turbulent mixing inside and above the canopy. These layers were considered to be in the stable regime when the temperature lapse rate (for the canopy layer calculated from observed temperatures at 4 and $21 \mathrm{~m}$ and for the abovecanopy layer calculated from temperatures observed at 21 

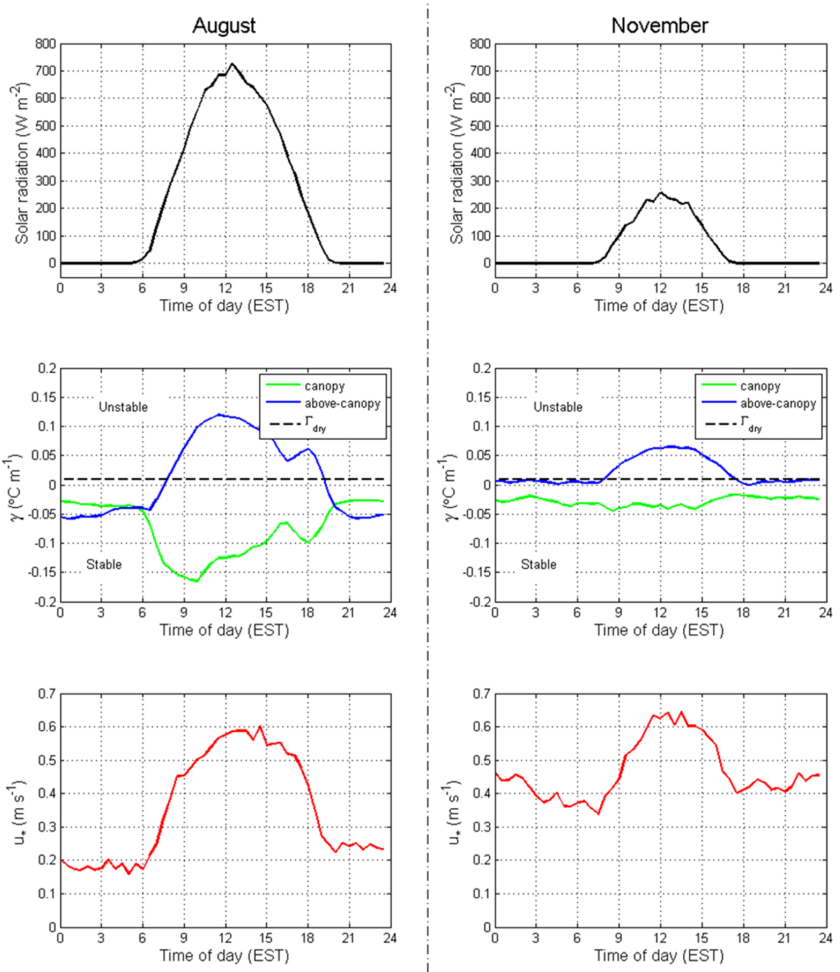

Fig. 3. Mean diurnal cycles of solar radiation, temperature lapse rates $(\gamma)$, and friction velocity $\left(u_{*}\right)$ in the above-canopy layer at UMBS for August and November 2008. The dashed line in the $\gamma$ plots denotes the dry adiabatic lapse rate $\left(\Gamma_{\text {dry }}\right)$ of $0.0098^{\circ} \mathrm{Cm}^{-1}$. $\gamma<\Gamma_{\text {dry }}$ is stable, $\gamma=\Gamma_{\text {dry }}$ is neutral, and $\gamma>\Gamma_{\text {dry }}$ is unstable.

and $34 \mathrm{~m}$ ) was below $0.0098^{\circ} \mathrm{Cm}^{-1}$, the dry adiabatic lapse rate (denoted as the dashed line in the lapse rate plots; Fig. 3). The atmosphere was considered unstable when the lapse rate was above the dry adiabatic lapse rate, and it was considered neutral when the lapse rate equaled the dry adiabatic lapse rate. The fact that changes in the above-canopy lapse rate, which reflect a transition from stable to unstable mixing conditions, coincide with the observed fast increase in friction velocity $>30 \mathrm{~min}$ after sunrise supports the use of these lapse rates as proxy for mixing conditions.

The daily amplitude (i.e. the difference between daily minimum and maximum) of the lapse rates decreased with a decrease in solar radiation from August to November. This suggests a decreasing role of buoyancy in turbulent exchanges. The timing when atmospheric stability changed varied as a function of the timing of sunrise and sunset implying also a dependence of the stability regime on solar radiation.

In August, stable atmospheric conditions were observed at night prior to sunrise through and above the canopy, indicating suppressed mixing between the two layers. Within 30 min after sunrise ( 06:30EST), the lapse rates diverge with enhanced mixing conditions in the above-canopy layer but increasing stability in the canopy layer. This response in- dicates differential heating of the above-canopy layer and the top of the canopy by the incoming solar radiation. The divergence in the lapse rates also indicates that the layers appear to be decoupled. These conditions suppress vertical mixing and cause accumulation of biogenically produced trace gases inside the canopy. As the sun sets ( 19:00 EST), the temperature lapse rates of the two layers converge to a lapse rate reflecting a stable regime.

In November, the mixing of air mass into the canopy layer was strongly suppressed. The canopy layer remained decoupled from the above-canopy layer throughout the day. The above-canopy layer mixing conditions transitioned from a neutral regime to an unstable regime about $30 \mathrm{~min}$ after sunrise $(\sim 08: 00 \mathrm{EST})$; after sunset $(\sim 17: 30 \mathrm{EST})$, the above-canopy layer lapse rate transitioned from unstable to neutral mixing conditions. The canopy layer lapse rate remained stable throughout the day.

\subsection{Chemical data}

\subsubsection{Seasonal data}

The evolution of $\mathrm{NO}_{\mathrm{x}, \mathrm{MO}}, \mathrm{NO}$, and $\mathrm{O}_{3}$ canopy mixing ratio profiles is shown in Fig. 2. Daily amplitudes of $\mathrm{NO}_{\mathrm{x}, \mathrm{MO}}, \mathrm{NO}$, and $\mathrm{O}_{3}$ gradually decreased over the season. For instance, the daily amplitude in $\mathrm{NO}_{\mathrm{x}, \mathrm{MO}}$ mixing ratios averaged at $1 \mathrm{ppbv}$ in August, then it declined to $0.5 \mathrm{ppbv}$ in November. However, the daily $\mathrm{NO}_{\mathrm{x}, \mathrm{MO}}$ maximum increased with time. The daily $\mathrm{NO}_{\mathrm{x}, \mathrm{MO}}$ maxima in August ranged between 0.4 and $10 \mathrm{ppbv}$ with a median of $2 \mathrm{ppbv}$. For NO, its daily amplitude averaged at $0.3 \mathrm{ppbv}$ in August, and then it declined to $0.2 \mathrm{ppbv}$ in November. The daily NO maximum in August ranged between 0.1 and $2 \mathrm{ppbv}$ with a median of $0.3 \mathrm{ppbv}$. $\mathrm{O}_{3}$ varied daily by an average of $20 \mathrm{ppbv}$ in August; the daily amplitude declined to $5 \mathrm{ppbv}$ in November. Its daily maximum ranged between 16 and $66 \mathrm{ppbv}$ with a median of 33 ppbv. These wide ranges in maximum $\mathrm{NO}_{\mathrm{x}, \mathrm{MO}}$ and $\mathrm{O}_{3}$ mixing ratios reflect that this site is influenced by contrasting biogenic and anthropogenic footprints, which may be dependent on season (Cooper et al., 2001).

\subsubsection{Diurnal data}

Mean diurnal vertical mixing ratio profiles of $\mathrm{NO}_{\mathrm{x}, \mathrm{MO}}, \mathrm{NO}$, and $\mathrm{O}_{3}$ for August and for November are shown in the color contour plots in Fig. 4.

- $\mathrm{NO}_{\mathrm{x}}$. The most prominent feature in the diurnal $\mathrm{NO}_{\mathrm{x}, \mathrm{MO}}$ cycle is the mixing ratio maximum seen during the early morning hours. Elevated $\mathrm{NO}_{\mathrm{x}, \mathrm{MO}}$ was observed throughout and above the canopy, with highest mixing ratios occurring right above the canopy. The diurnal cycle of $\mathrm{NO}_{\mathrm{x}, \mathrm{MO}}$ also shows elevated levels of $\mathrm{NO}_{\mathrm{x}, \mathrm{MO}}$ throughout the canopy during the night $(\sim 0.5$ to $0.7 \mathrm{ppbv})$ and lower levels during the latter part of the day $(\sim 0.3 \mathrm{ppbv})$. The daily amplitude in $\mathrm{NO}_{\mathrm{x}, \mathrm{MO}}$ 

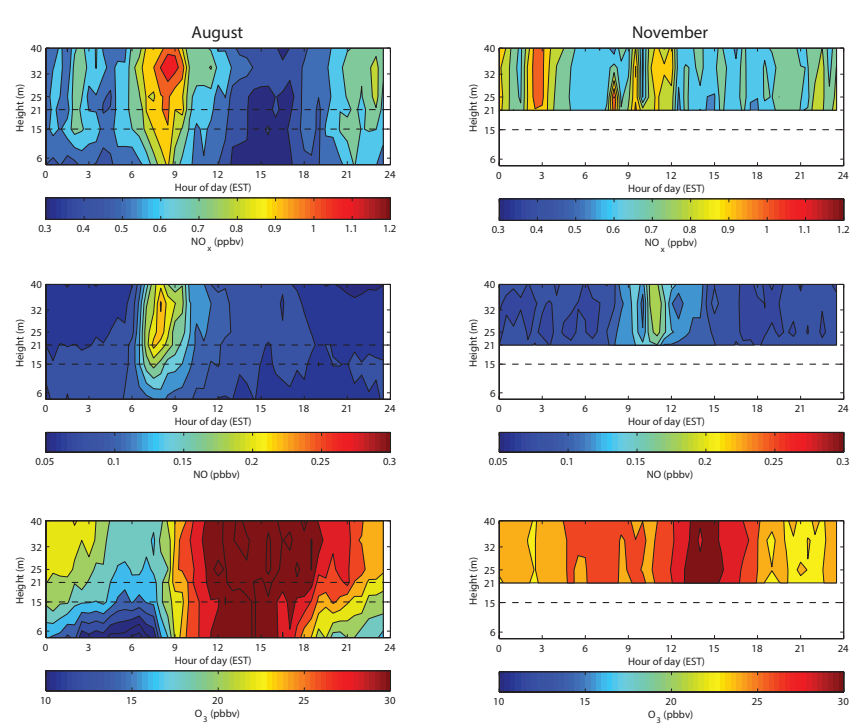

Fig. 4. Mean diurnal cycles of $\mathrm{NO}_{\mathrm{x}, \mathrm{MO}}, \mathrm{NO}$, and $\mathrm{O}_{3}$ mixing ratio profiles from the UMBS AmeriFlux site for August and November 2008. The area between the dashed lines in the plots denotes the crown layer. Gaps in the data below the crown layer in November are due to failures in the 4 and $15 \mathrm{~m}$ switching valves.

mixing ratio and the magnitude of the morning peak are smaller in November than in August. The differences in the nocturnal $\mathrm{NO}_{\mathrm{x}, \mathrm{MO}}$ mixing ratios between August and November are small.

- NO. The diurnal variation of NO also clearly shows a morning peak above the canopy after sunrise, coinciding with the morning $\mathrm{NO}_{\mathrm{x}, \mathrm{MO}}$ maximum. This coincidence in timing of the NO peak suggests that this $\mathrm{NO}$ is formed from $\mathrm{NO}_{2}$ photodissociation. During the night, despite the previously discussed canopy stratification, observed understory layer NO levels are slightly $(<0.1 \mathrm{ppbv})$ larger than the above-canopy layer NO levels, which indicates that soil NO emission may have minor influence on the nocturnal NO profile.

- $\mathrm{O}_{3}$. Ozone increased throughout the daylight hours reaching maxima in the early afternoon. Mixing ratios then began leveling out in the late afternoon and began dropping steadily throughout the evening and night until approximately sunrise time. In the understory layer ozone declined at a faster rate, with ozone loss first occurring right at the forest ground surface, and then from there slowly reaching up to the crown layer. During nighttime ozone mixing ratios above-canopy remained $\sim 10$ ppbv higher than in the understory. Between 08:00 and 09:00 EST, the $\mathrm{O}_{3}$ mixing ratio in the understory rapidly increased to levels measured in the above-canopy layer. During the day, from 10:00 to 17:00 EST, the vertical $\mathrm{O}_{3}$ profile evolved uniformly all throughout below and above the canopy, with average
$\mathrm{O}_{3}$ maxima of $\sim 30 \mathrm{ppbv}$. It is notable that the temporal evolution of the nighttime $\mathrm{O}_{3}$ loss near the ground coincided with the nighttime accumulation of $\mathrm{NO}_{\mathrm{x}, \mathrm{MO}}$. The main connecting processes here are limited turbulent transport and soil NO emissions explaining the accumulation of $\mathrm{NO}_{\mathrm{x}, \mathrm{MO}}$ near the soil surface. It also partly explains the decrease in $\mathrm{O}_{3}$ due to a reduced resupply of $\mathrm{O}_{3}$ from higher up in the canopy and surface layer. The resupply of $\mathrm{O}_{3}$ is insufficient to compensate for surface deposition and chemical destruction from reaction with soil-emitted NO. The NO mixing ratios are so small that the titration of $\mathrm{O}_{3}$ would only be a minor term in $\mathrm{O}_{3}$ destruction. Similar to the $\mathrm{NO}_{\mathrm{x}, \mathrm{MO}}$ diurnal cycle, the daily amplitude in the $\mathrm{O}_{3}$ mixing ratio was smaller in November than in August.

\subsubsection{Air mass advection}

Figure 5 shows a wind-pollution rose of the measured trace gases for August and for November. The length of the wedge corresponds to the frequency of readings from particular wind sectors, while the color corresponds to the magnitude of the pollutant mixing ratios. These wind-pollution roses show that the two predominant wind directions at UMBS are from the southeast (SE; $112^{\circ}-157^{\circ}$, occurs $\sim 20 \%$ ) and the northwest (NW; $292^{\circ}-315^{\circ}$, occurs $\sim 23 \%$ ), and somewhat less, from the west. The wind distribution did not change much between August and November.

The $\mathrm{O}_{3}$-wind rose plots show enhanced $\mathrm{O}_{3}$ being transported during SE-SW winds $\left(112^{\circ}-247^{\circ}\right)$, most notably for November. During November, elevated $\mathrm{O}_{3}$ levels were also observed during southwest (SW) winds. Relative to $\mathrm{O}_{3}$, $\mathrm{NO}_{\mathrm{x}, \mathrm{MO}}$ - and to a lesser extent - NO, display a more pronounced wind direction dependency, with elevated levels clearly being associated to SE and SW wind directions. During $\mathrm{NW}$ winds, $\mathrm{NO}_{\mathrm{x}, \mathrm{MO}}$ remained $<1 \mathrm{ppbv}$ during most times, whereas SE-SW winds consistently were associated with $\mathrm{NO}_{\mathrm{x}, \mathrm{MO}}>2 \mathrm{ppbv}$. There are major urban centers from 350 to $450 \mathrm{~km}$ upwind of UMBS in the SE-SW sectors (i.e. Detroit, Milwaukee, and Chicago); these urban areas are likely the source regions for the elevated $\mathrm{NO}_{\mathrm{x}, \mathrm{MO}}$ transported to the site.

The diurnal breakup of the wind roses (Supplement Fig. S1) shows that the site experienced a diurnal shifting of transport direction. During August, from midnight to 06:00 EST, wind directions were predominantly from the NW and the SE - and occasionally from the W. Winds then gradually shifted to NW and SE-SW. During sunrise (06:0009:00EST), wind directions were predominately from the NW and the SE-SW. From the morning hours to after sunset (09:00-21:00 EST), the frequency of SE-SW winds declined and the majority of the winds came from the W-NE directions. During the late evening (21:00-24:00 EST), the frequency of SE wind directions increased leading back to predominately NW and SE winds. 

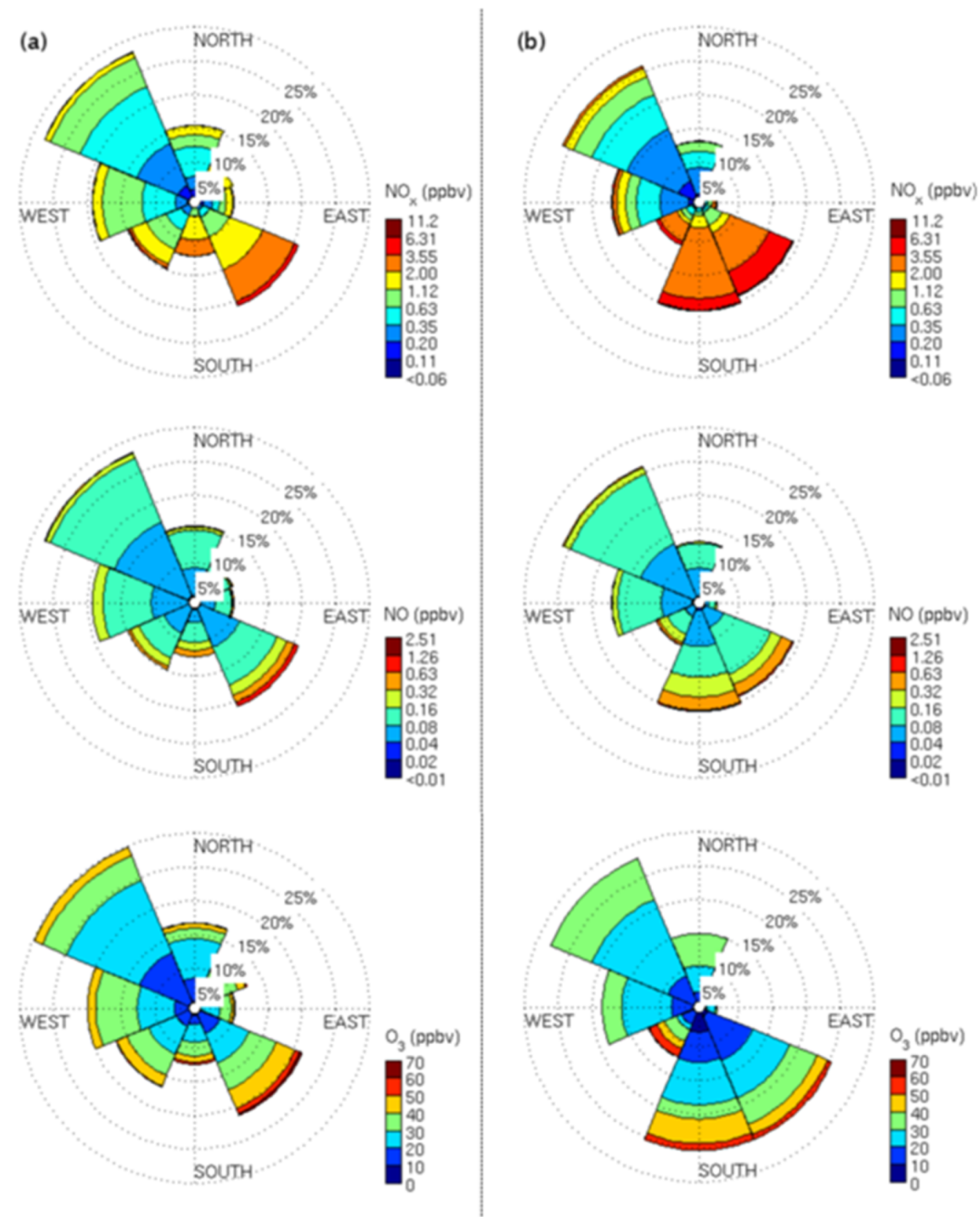

Fig. 5. Wind-pollution rose for $\mathrm{NO}_{\mathrm{x}, \mathrm{MO}}, \mathrm{NO}$, and $\mathrm{O}_{3}$ determined for (a) August and for (b) November using data from the $46 \mathrm{~m}$ level wind sensor and $34 \mathrm{~m}$ level gas inlet (see Fig. 1).

The diurnal frequency of wind directions in November varied from August in that the SE-S wind directions stayed more frequent throughout the night and day (Fig. S1). However, from sunrise until after sunset (09:00-21:00 EST), the SE-S wind direction dominance decreased and the frequency of W-NW wind directions increased. The steady frequency of SE-S wind directions in November may contribute to the smaller daily variation observed for $\mathrm{NO}_{\mathrm{x}, \mathrm{MO}}$ and $\mathrm{O}_{3}$ levels than that observed in August, as winds from these directions tend to bring elevated levels of $\mathrm{NO}_{\mathrm{x}, \mathrm{MO}}$ and $\mathrm{O}_{3}$ into the region.

The frequency of NO maxima increased during winds from the southerly directions (SE-SW sectors) (06:00-
09:00 EST for August; 09:00-12:00 EST for November). Therefore, wind direction seems to be a key factor in the observed variations in gas mixing ratio. Cooper et al. (2001) and Thornberry et al. (2001) also observed higher levels of $\mathrm{NO}_{\mathrm{x}}$ and $\mathrm{O}_{3}$ during transport from the SE-SW sectors at UMBS. Conversely, they saw lower levels of $\mathrm{NO}_{\mathrm{x}}$ and $\mathrm{O}_{3}$ with NW winds. Back trajectory analysis done by Cooper et al. (2001) and by Alaghmand et al. (2011) showed that air transported to the site during SE-SW winds had passed through the three major urban areas of Detroit, Milwaukee, and Chicago. The lack of $\mathrm{NO}_{\mathrm{x}}$ increases during $\mathrm{NW}$ winds at night indicates the lack of major local emissions from that wind sector (Thornberry et al., 2001). Consequently, these 


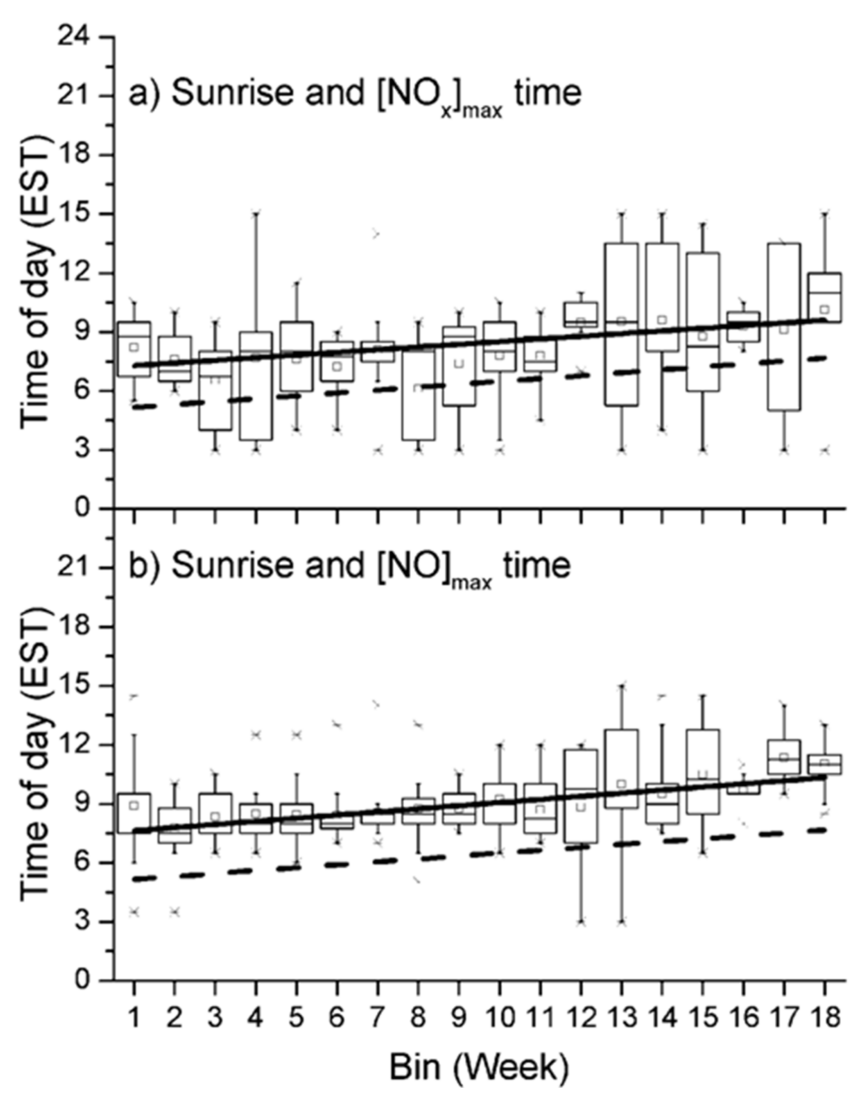

Fig. 6. The relationship between sunrise and time of observed (a) $\mathrm{NO}_{\mathrm{x}, \mathrm{MO}}$ and (b) NO maxima from 03:00 to 15:00 EST from each sampling inlet. The dashed lines denote the change in time of sunrise over 18 weeks (five months) in 2008 at UMBS (regression: $\left.y=0.147 x+5.01, r^{2}=0.999\right)$. Data for 7 days, staring on 19 July were binned together and are displayed as box-andwhisker plots that depict the mean, median, 25 and 75 percentile, and 5 and 95 percentile values. The solid regression lines were fit to the weekly median data. They denote the average change in when the $\mathrm{NO}_{\mathrm{x}, \mathrm{MO}}$ and the $\mathrm{NO}$ maxima were observed (regression: (a) $y=0.135(\mathrm{SE} \pm 0.0355) x+7.14(\mathrm{SE} \pm 0.384), r^{2}=0.478$ and (b) $\left.y=0.159(\mathrm{SE} \pm 0.0321) x+7.46(\mathrm{SE} \pm 0.348), r^{2}=0.605\right)$.

wind flow analyses support the hypothesis that the $\mathrm{NO}_{\mathrm{x}, \mathrm{MO}}$ increases seen at UMBS are most likely non-local. The windpollution rose and wind rose analyses provide a strong indication that advection plays a major role in the observed morning maxima of $\mathrm{NO}_{\mathrm{x}, \mathrm{MO}}$ and $\mathrm{NO}$. This will be further substantiated by the sensitivity analysis with the model for this site presented in Sect. 5.2.

\subsection{Seasonal shift of the morning $\mathrm{NO}_{\mathrm{x}}$ peak}

Figure 6 shows the relationship between the time of sunrise and the occurrence of $\mathrm{NO}_{\mathrm{x}, \mathrm{MO}}$ and $\mathrm{NO}$ maxima from July to November for data falling into the 03:00 to 15:00 EST window (Supplement Fig. S2). The time of sunrise was determined when the radiation sensor registered $>10 \mathrm{~W} \mathrm{~m}^{-2}$ in- crease from its nighttime reading $\left(\sim 0.1 \mathrm{Wm}^{-2}\right)$. The daily sunrise time determinations are not plotted in the figure, but instead the linear regression line fit through the data is shown. The slope of the regression line indicates that the sunrise time shifted $\sim 0.147 \mathrm{hwk}^{-1}$. The time of the $\mathrm{NO}_{\mathrm{x}, \mathrm{MO}}$ peak was determined from the occurrence of the maximum $\mathrm{NO}_{\mathrm{x}, \mathrm{MO}}$ reading at all measurement heights, box-and-whisker plots in Fig. 6 show the statistical distribution of the weekly data. The data in Fig. 6a clearly illustrate that the majority of the daily $\mathrm{NO}_{\mathrm{x}, \mathrm{MO}}$ maxima measured from each tower inlet level occurred within a few hours after sunrise. A linear regression line through the median values of the weekly distribution plot of the daily $\mathrm{NO}_{\mathrm{x}, \mathrm{MO}}$ maxima $\left(y=0.136 x+7.14, r^{2}=0.478\right.$, where $y$ is sunrise time and $x$ is the weekly bin) indicates that the time of the $\mathrm{NO}_{\mathrm{x}, \mathrm{MO}}$ maximum shifted by $\sim 0.136$ (standard error \pm 0.0355$) \mathrm{hwk}^{-1}$, similar to the change in sunrise time. The difference in the $y$-intercept of the two (sunrise and $\mathrm{NO}_{\mathrm{x}, \mathrm{MO}}$ maxima) regression lines can be used as an indicator of the delay of the $\mathrm{NO}_{\mathrm{x}, \mathrm{MO}}$ maximum relative to sunrise; the offset between the two regression analyses yields a result of $\sim 2 \mathrm{~h}$.

Figure $6 \mathrm{~b}$ shows the relationship between sunrise time and the time of maximum NO. The linear regression through the median weekly NO maxima indicates that the time of NO maximum shifted by $\sim 0.159$ (standard error \pm $0.0321) \mathrm{hwk}^{-1}$. The lag between sunrise and when the NO maximum occurs is $\sim 2.5 \mathrm{~h}$. Notice that this corresponds to a time approximately half an hour after the $\mathrm{NO}_{\mathrm{x}, \mathrm{MO}}$ maximum time.

This analysis suggests that the sunrise time and the occurrence of the $\mathrm{NO}_{\mathrm{x}, \mathrm{MO}}$ maximum are closely linked. Consequently, it appears that solar radiation driven processes, such as thermodynamically driven mixing and photochemistry, are the governing processes in the $\mathrm{NO}_{\mathrm{x}, \mathrm{MO}}$ and $\mathrm{NO}$ morning peak occurrence.

\section{Model results and discussion}

\subsection{Model validation and baseline performance}

The model was used to simulate the month of August conditions for UMBS. To assess the performance of the model on simulating the main features of the site-specific micrometeorology and chemical boundary conditions, the results of the simulations were compared against observed incoming solar radiation, above-canopy air temperature at $34 \mathrm{~m}$, abovecanopy friction velocity (Fig. 7) and the $\mathrm{NO}_{\mathrm{x}, \mathrm{MO}}$ and $\mathrm{O}_{3}$ mixing ratios (Fig. 8).

Figure 7 shows that the SCM was able to simulate the diurnal cycle in radiation and temperature quite well as reflected by a strong correlation between measured and simulated parameter values $\left(r^{2}>0.95\right)$. However, the model underestimated the daytime maximum friction velocity with a too strong decrease in turbulence intensity simulated by 

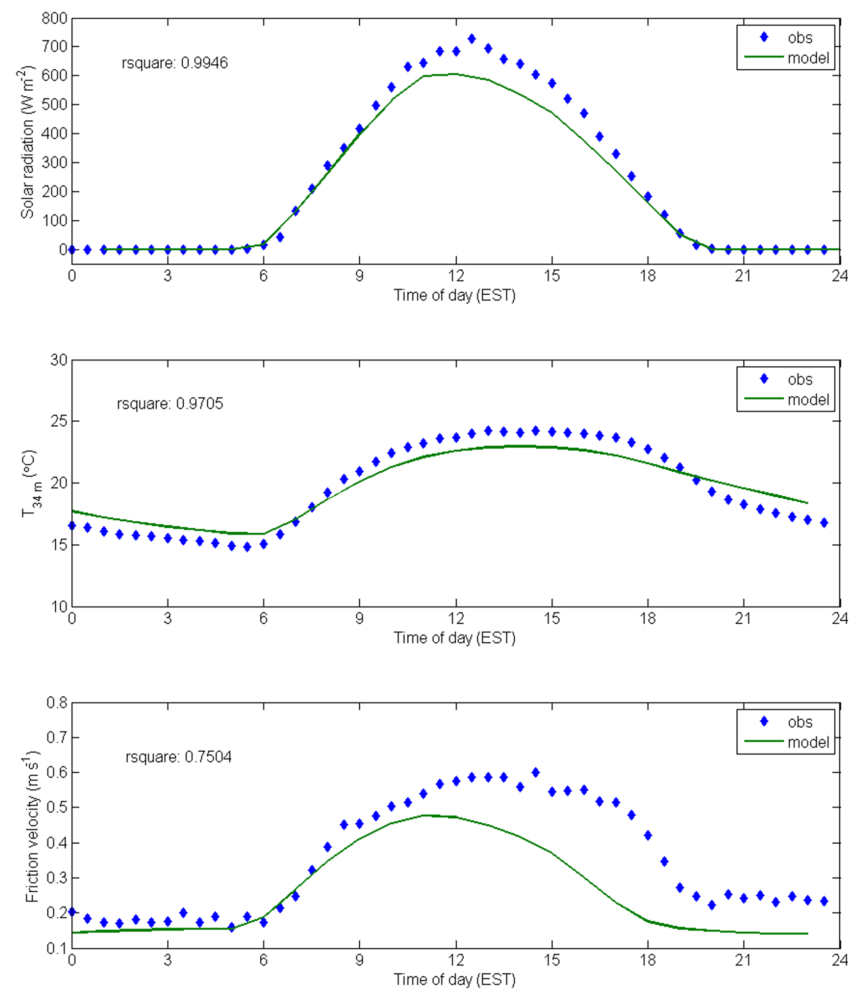

Fig. 7. Observed and modeled (SCM) diurnal variation of solar radiation, above-canopy temperature at $34 \mathrm{~m}$, and above-canopy friction velocity at $46 \mathrm{~m}$ for August 2008 at the UMBS AmeriFlux tower. The correlation coefficient, $r^{2}$, between the observed and the modeled data is noted in each plot.

the model in the afternoon. The latter seems to be due to a misrepresentation of the stability effect for unstable conditions in the SCM. Good agreement between the simulated and observed friction velocity was produced when soil moisture was reduced in the SCM, however, this resulted in simulated temperatures that were $4{ }^{\circ} \mathrm{C}$ warmer than observations.

Figure 8 shows the mean and median diurnal cycles of observed and simulated $\mathrm{NO}_{\mathrm{x}, \mathrm{MO}}$ and $\mathrm{O}_{3}$ mixing ratios. The difference between the mean and median of the observed data is largest during the midnight to early morning hours (00:0006:00 EST). This feature indicates that the influence exerted by occasional events with elevated $\mathrm{NO}_{\mathrm{x}, \mathrm{MO}}$ is higher during those hours than during the remainder of the day. $\mathrm{O}_{3}$ shows a similar behavior, but with generally smaller differences between the median and mean mixing ratios. In addition, the difference between the mean and the median mixing ratios reflects the large temporal variability in the observations of air masses that are enhanced in $\mathrm{NO}_{\mathrm{x}, \mathrm{MO}}$ and $\mathrm{O}_{3}$ under suppressed mixing conditions.

The simulated diurnal means of $\mathrm{NO}_{\mathrm{x}, \mathrm{MO}}$ and $\mathrm{O}_{3}$ in Fig. 8 include the contribution by advection as the model was nudged towards the observed above-canopy $\mathrm{NO}_{\mathrm{x}, \mathrm{MO}}$ and $\mathrm{O}_{3}$ mixing ratios. In other words, the simulations reflect the net
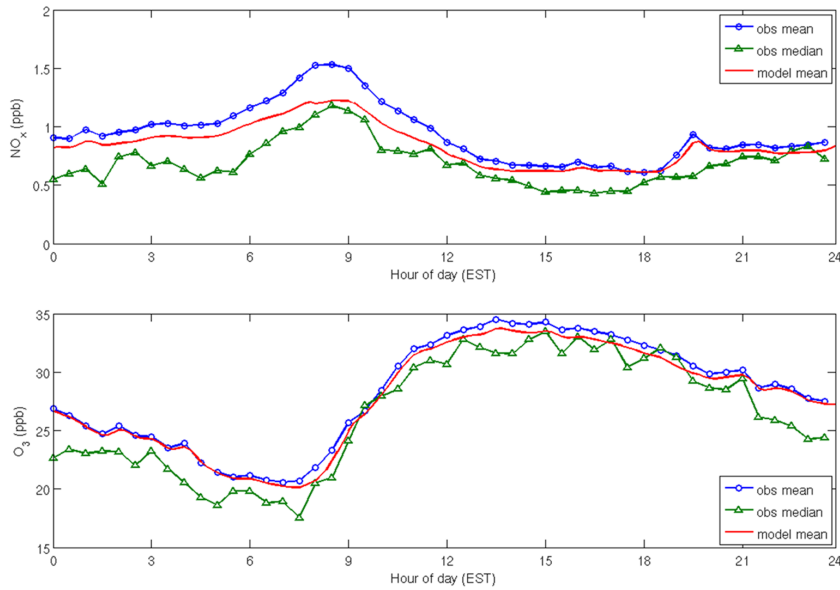

Fig. 8. Observed August mean (blue circle) and median (green triangle) diurnal cycle in $\mathrm{NO}_{\mathrm{x}, \mathrm{MO}}$ and $\mathrm{O}_{3}$ mixing ratios above the canopy at $34 \mathrm{~m}$. Also shown are the simulated August mean (red line) diurnal mixing ratios.

result of the explicitly resolved sources, sinks, and vertical exchange processes complemented by the implicitly added "advection" term, which considers changes in chemical composition of air advected to the site. Consequently, the simulated diurnal $\mathrm{O}_{3}$ above-canopy layer mixing ratios (Fig. 8) nearly resemble the observed data as anticipated. In contrast, agreement between simulated and observed mean $\mathrm{NO}_{\mathrm{x}, \mathrm{MO}}$ is less. The disagreement is greatest in the early morning hours, where simulated $\mathrm{NO}_{\mathrm{x}}$ is $\sim 0.3 \mathrm{ppbv}$ smaller compared to the observed peak mixing ratio of $\sim 1.5 \mathrm{ppbv}$. The fact that the model output shows better agreement with the median data suggests that the morning $\mathrm{NO}_{\mathrm{x}, \mathrm{MO}}$ peak seen in the August mean data reflects the role of some large peak values associated with individual transport events, which are underrepresented by the model. Apparently, these events are not captured by the model for the selected nudging relaxation time of $300 \mathrm{~s}$. This underestimation of the above-canopy layer $\mathrm{NO}_{\mathrm{x}, \mathrm{MO}}$ peak mixing ratios has obvious consequences for explanation of the observed early morning peak in NO, which we discuss in later sections.

\subsection{Sensitivity of the above and within canopy morning $\mathrm{NO}_{\mathrm{x}}$ peak}

\subsubsection{Soil emissions}

The sensitivity of $\mathrm{NO}_{\mathrm{x}}, \mathrm{NO}$, and $\mathrm{O}_{3}$ to soil $\mathrm{NO}$ emissions is shown in Fig. 9 as the difference between observed and simulated diurnal mixing ratio profiles $(\Delta=$ simulated observed). The soil NO emission rates tested include a "zero" soil NO emissions flux $(0 \times$; Fig. $9 b)$, a soil NO emission flux reflecting reported values $\left(0.07 \mathrm{ng} \mathrm{N} \mathrm{m}^{-2} \mathrm{~s}^{-1}\right.$, Table 1) $1 \times, 10 \times$, and $25 \times$ increases of the reported values Fig. $9 \mathrm{c}$, $\mathrm{d}, \mathrm{e})$. Note that the $25 \times$ case is most likely an unrealistic and 

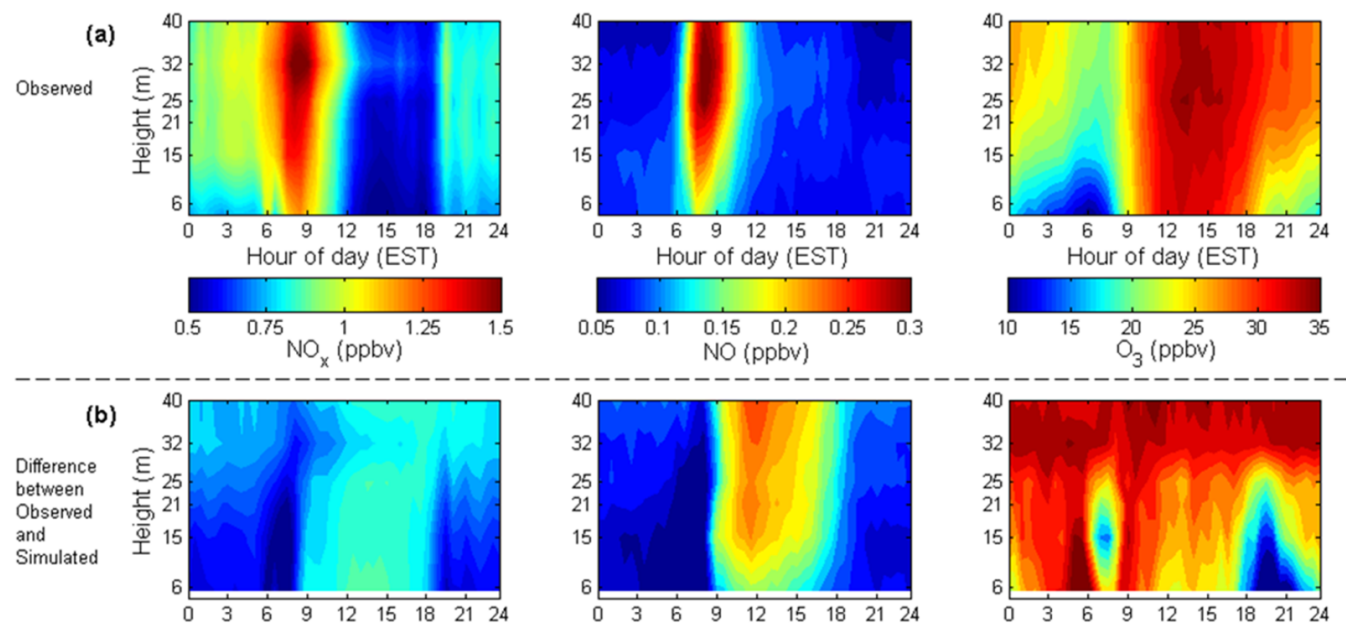

(c)
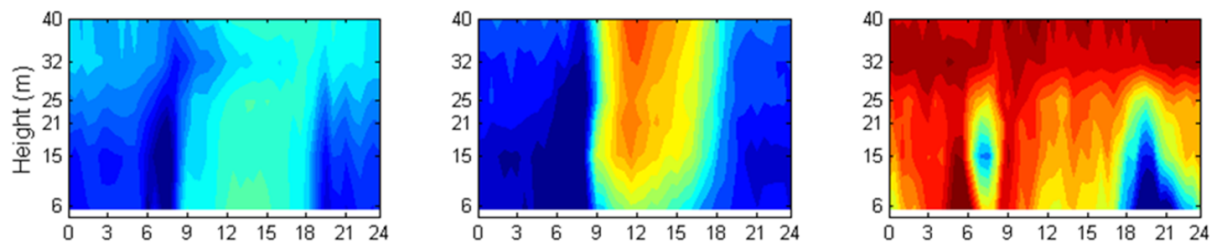

(d)
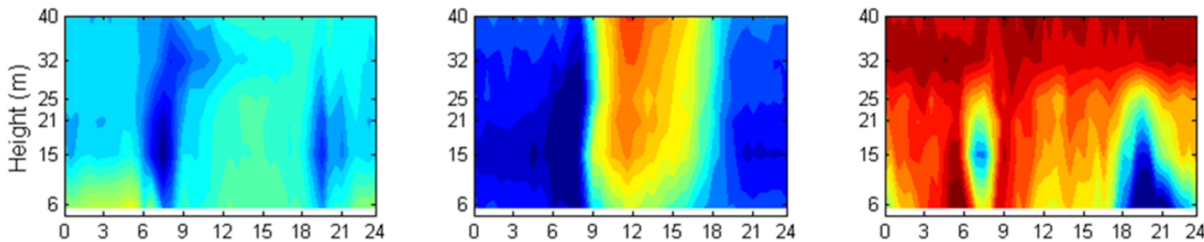

(e)
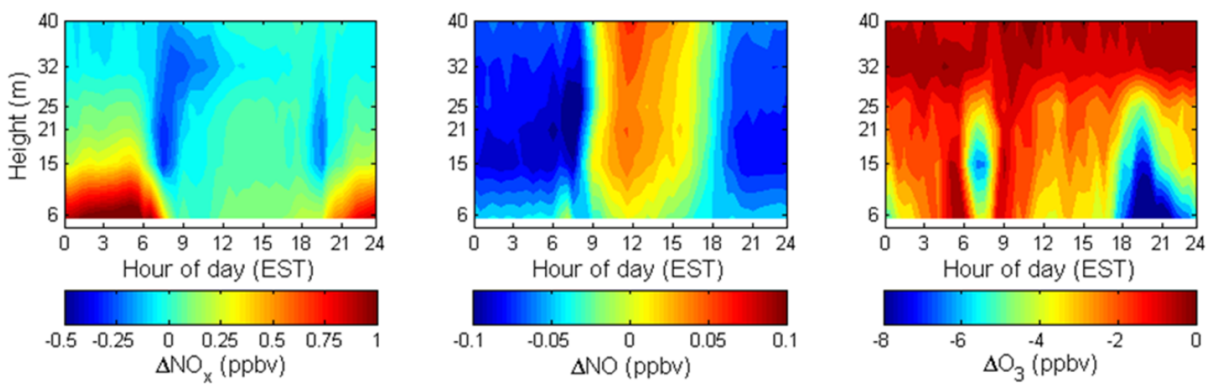

Fig. 9. (a) The observed mean diurnal mixing ratio profiles of $\mathrm{NO}_{\mathrm{x}, \mathrm{MO}}, \mathrm{NO}$, and $\mathrm{O}_{3}$. Plots (b) through (e) depict the difference between the observed and simulated mean $(\Delta=$ simulated - observed) diurnal cycle of the mixing ratio profiles of these gases as a function of soil NO emission for August 2008. (b) Case for "zero" soil emission. (c) Case for default soil emission $\left(1 \times, 0.07 \mathrm{ng} \mathrm{Nm}^{-2} \mathrm{~s}^{-1}\right.$; see Table 1$)$. (d) Case for 10 times the default soil emission $(10 \times)$. (e) Case for 25 times the soil emission $(25 \times)$.

extreme case, as it is significantly larger than what was measured (Nave et al., 2011), but it was applied here for the purpose of testing the sensitivity of the model. In addition, these simulations on the soil $\mathrm{NO}_{\mathrm{x}}$ emission influence did not include any $\mathrm{NO}_{x}$ contribution by foliage emissions. In Fig. 9be, a positive delta value implies that the model overestimates measured mixing ratios, while a negative delta value means an underestimation in the simulated mixing ratio.
- $\mathrm{NO}_{\mathrm{x}}$. The observed nighttime minimum of $\mathrm{NO}_{\mathrm{x}, \mathrm{MO}}$ seen in the data (Fig. 9a) near the forest floor points at the role of understory sinks of $\mathrm{NO}_{\mathrm{x}, \mathrm{MO}}$, e.g., surface deposition or chemical destruction, of a magnitude larger compared to the soil $\mathrm{NO}_{\mathrm{x}, \mathrm{MO}}$ source. The $0 \times$ and $1 \times$ soil NO emission flux simulations resulted in $\mathrm{NO}_{\mathrm{x}}$ profiles that are similar to each other and resemble the observed data. Apparently, $\mathrm{NO}_{\mathrm{x}}$ in the crown and abovecanopy layers is rather insensitive to the magnitude of the soil NO emission flux. Even the further increases of 

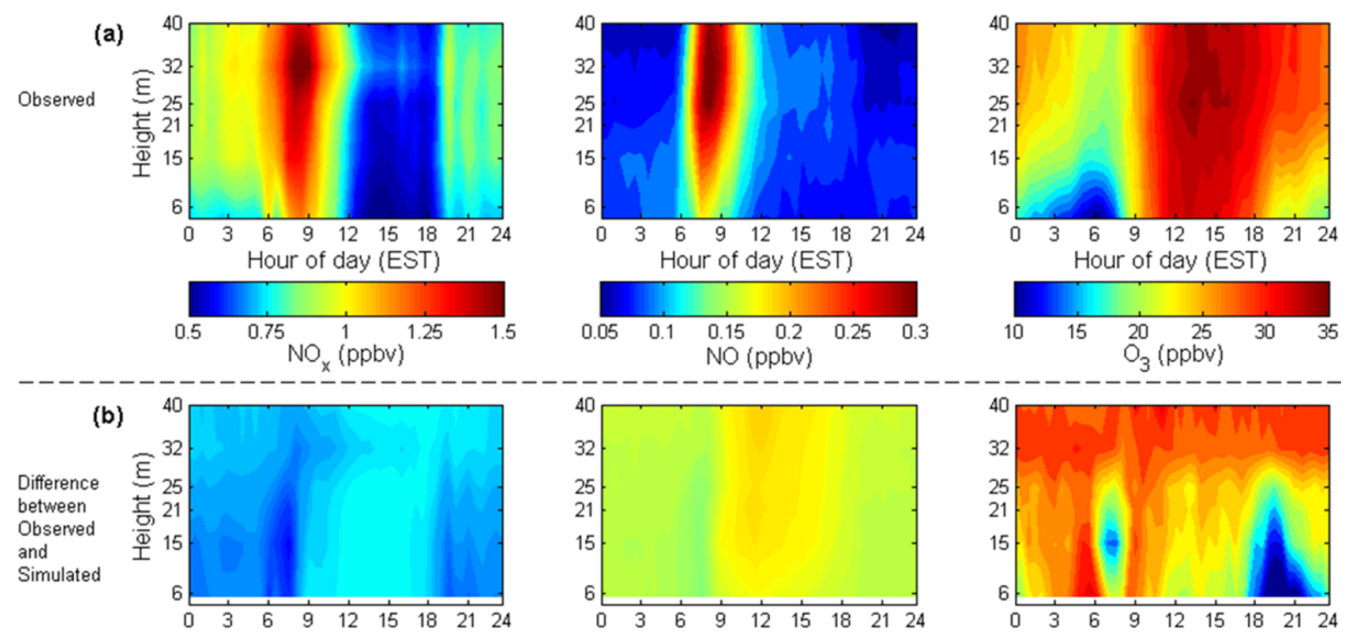

(c)
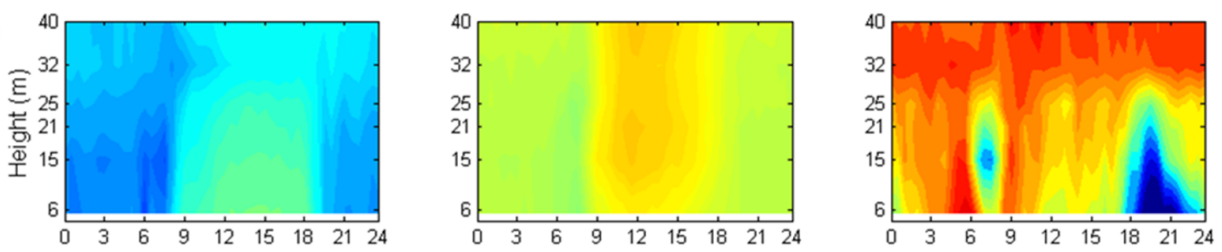

(d)
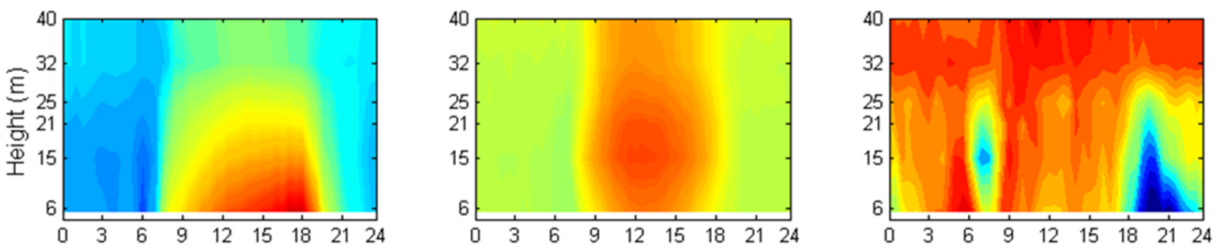

(e)
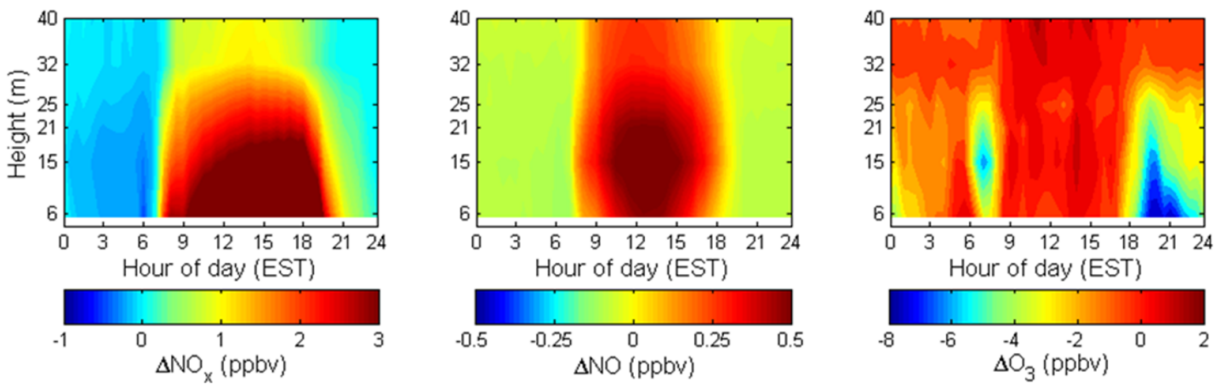

Fig. 10. Similar to Fig. 9 but for sensitivity towards foliage $\mathrm{NO}_{\mathrm{x}}$ emission. (a) The observed mean diurnal mixing ratio profiles, (b) case for "zero" foliage emission, (c) $1 \times$ case, $($ d) $10 \times$ case, (e) $25 \times$ case.

the NO soil flux $(10 \times$ and $25 \times)$ did not produce noticeable changes to the $\mathrm{NO}_{\mathrm{x}}$ profiles, except in the understory layer. For the $1 \times$ soil $\mathrm{NO}_{\mathrm{x}}$ source, the model predicted $\mathrm{NO}_{\mathrm{x}}$ minimum mixing ratios of $\sim 0.3 \mathrm{ppbv}$ in the understory layer in the early night compared to observed understory $\mathrm{NO}_{\mathrm{x}, \mathrm{MO}}$ levels of $\sim 0.7 \mathrm{ppbv}$. This suggests that the model NO soil flux that we selected for this study - based on observed soil NO emission fluxes - appears to be too small. The $10 \times$ simulation of $0.7 \mathrm{ng} \mathrm{N} \mathrm{m}^{-2} \mathrm{~s}^{-1}$ actually results in a better agreement between simulated and observed $\mathrm{NO}_{\mathrm{x}}$ inside the canopy.
This finding concurs with Alaghmand et al. (2011), who applied a soil NO flux at UMBS of $\sim 180 \mathrm{nmolm}^{-2} \mathrm{~h}^{-1}$ $\left(\sim 0.7 \mathrm{ng} \mathrm{Nm}^{-2} \mathrm{~s}^{-1}\right)$ in their work. They based this number on an unpublished dataset from Carleton et al. (2003). We use NO effluxes of $\sim 0.2 \mu \mathrm{g} \mathrm{N} \mathrm{m}^{-2} \mathrm{~h}^{-1}$ (or $\sim 0.07 \mathrm{ng} \mathrm{N} \mathrm{m}^{-2} \mathrm{~s}^{-1}$ ) measured around the AmeriFlux site in the summer of 2008 by Nave et al. (2011). At sunrise, the model predicted an increase in $\mathrm{NO}_{\mathrm{x}}$ mixing ratios throughout the canopy, whereas the observations showed mainly an increase in $\mathrm{NO}_{\mathrm{x}}$ above the canopy (Fig. 9a, b). Observed $\mathrm{NO}_{\mathrm{x}, \mathrm{MO}}$ mixing ratios were as 
large as $1.5 \mathrm{ppbv}$, while the model predicted abovecanopy maximum $\mathrm{NO}_{\mathrm{x}}$ mixing ratios up to $\sim 1 \mathrm{ppbv}$, even for the $10 \times$ soil emission case. The model predicted minimum $\mathrm{NO}_{\mathrm{x}}$ mixing ratios in the canopy layer in the late afternoon and evening consistent with the data from 12:00 to 18:00 EST. For the "unreasonably" high $25 \times$ soil emission case, the model predicted levels of $\mathrm{NO}_{\mathrm{x}}$ near the forest surface about $1 \mathrm{ppbv}$ larger than observed during the night. Yet even with this high soil $\mathrm{NO}_{\mathrm{x}}$ flux, there was no improvement in the representation of the above-canopy early morning $\mathrm{NO}_{\mathrm{x}}$ peak.

- NO. For all soil NO flux scenarios, the daytime NO mixing ratio profiles were slightly overestimated in the canopy layer. The model simulated NO canopy mixing ratios reasonably well for all soil NO emission cases with differences of $<0.05 \mathrm{ppbv}$. However, the model underestimated the nocturnal NO mixing ratios in the crown and above-canopy layers by $>0.05 \mathrm{ppbv}$. The $25 \times$ soil emission case shows some enhancement in the simulated NO mixing ratios in the understory layer, but the NO increase is only confined to the understory layer, whereas the observations showed nocturnal NO mixing ratios of $\sim 0.1 \mathrm{ppbv}$ throughout the canopy. The simulations show a similar above-canopy NO peak as seen in the data. However, the NO maxima simulated by the model are 0.05 to $0.1 \mathrm{ppbv}$ lower than observed. During afternoon hours, the model over-predicts NO by $0.05-$ $0.1 \mathrm{ppbv}$ throughout the canopy. Again, the increase in the soil $\mathrm{NO}_{\mathrm{x}}$ flux exerted little influence on the abovecanopy morning NO peak formation.

$-\mathrm{O}_{3}$. Regardless of the changes in soil emission rates, the model reasonably predicted absolute $\mathrm{O}_{3}$ levels, the mixing ratio profiles of $\mathrm{O}_{3}$, and the timing of the breakup of the nighttime $\mathrm{O}_{3}$ gradient at sunrise. The SCM underestimated $\mathrm{O}_{3}$ mixing ratios in the understory layer at sunrise (06:00-09:00 EST) and during the late evening and nighttime (18:00-24:00 EST). This effect may be related to an overestimation of canopy sinks (e.g., foliage or soil deposition, chemical destruction) or an underestimation of downward turbulent transport inside the canopy (Fig. 7, Sect. 5.1).

\subsubsection{Foliage emissions}

Hanson and Lindberg (1991) compiled a report showing evidence for deposition of $\mathrm{NO}_{\mathrm{x}}$ onto surfaces such as leaves, bark, and soil. It is possible that residual $\mathrm{NO}_{2}$ could be "trapped" in the canopy via deposition onto leaves. At sunrise, the deposited $\mathrm{NO}_{2}$, either as $\mathrm{NO}_{2}$ or in the form of $\mathrm{HONO}$ or $\mathrm{HNO}_{3}$, would undergo photolysis to ultimately create $\mathrm{NO}$ above the canopy. The sensitivity of $\mathrm{NO}_{\mathrm{x}}, \mathrm{NO}$, and $\mathrm{O}_{3}$ to a foliage $\mathrm{NO}_{\mathrm{x}}$ emission flux is shown in Fig. 10. The foliage $\mathrm{NO}_{\mathrm{x}}$ emission rates are based on leaf nitrate content reported by Zhou et al. (2011) (see Table 1), where we assumed that photolysis of nitrate on the surface of the leaves results in foliage $\mathrm{NO}_{2}$ and $\mathrm{HONO}$ emissions (hence, referred to as foliage $\mathrm{NO}_{\mathrm{x}}$ emissions). The simulated cases include a "zero" foliage $\mathrm{NO}_{\mathrm{x}}$ emissions flux ( $0 \times$; Fig. 10b), an assumed foliage $\mathrm{NO}_{\mathrm{x}}$ emissions flux based on the reported leaf nitrate value $\left(0.83 \mathrm{nmol} \mathrm{cm}^{-2}\right.$, Table 1$)(1 \times$; Fig. $10 \mathrm{c})$, and increased foliage $\mathrm{NO}_{\mathrm{x}}$ emission fluxes based on 10 and 25 times increases in the reported leaf nitrate levels $(10 \times$ and $25 \times$, see Table 1; Fig. 10d, e). In Fig. 10b-e, a positive delta value means that the model has overestimated the mixing ratio, while a negative delta implies an underestimation in the simulated mixing ratio value.

- $\mathrm{NO}_{\mathrm{x}}$. The increase in foliage $\mathrm{NO}_{\mathrm{x}}$ emissions causes increasing $\mathrm{NO}_{\mathrm{x}}$ mixing ratios during the sunlit daytime hours, with most of this $\mathrm{NO}_{\mathrm{x}}$ growth seen in the understory layer where $\mathrm{NO}_{\mathrm{x}}$ accumulates due to slower removal by transport, chemistry, and deposition. For the $10 \times$ and $25 \times$ simulation cases, resulting $\mathrm{NO}_{\mathrm{x}}$ mixing ratios are far above the observed data. These comparisons do not provide evidence that foliage emission have a determining influence on the above-canopy morning $\mathrm{NO}_{\mathrm{x}, \mathrm{MO}}$ peak.

- NO. NO results are similar to $\mathrm{NO}_{\mathrm{x}}$, except that the effect on NO is not constrained to the understory layer but is notable throughout the canopy and above-canopy layer. Yet again, increasing the foliage $\mathrm{NO}_{\mathrm{x}}$ emission rate above the default value yields atmospheric $\mathrm{NO}$ levels that exceed the observations.

$-\mathrm{O}_{3}$. Increasing the foliage $\mathrm{NO}_{\mathrm{x}}$ flux had little influence on the $\mathrm{O}_{3}$ mixing ratios. Likewise to the sensitivity of soil NO emissions (Sect. 5.2.1), the underestimation of $\mathrm{O}_{3}$ in the understory layer during sunrise and late evening hours seen in the comparison between the observed and the simulated values is insensitive to changes in foliage $\mathrm{NO}_{\mathrm{x}}$ flux.

\subsubsection{Leaf-scale bidirectional exchanges of $\mathrm{NO}_{2}$}

To further diagnose the contribution of the different processes that influence the diurnal variability in $\mathrm{NO}_{\mathrm{x}, \mathrm{MO}}$, the simulated process tendencies for the default conditions (expressed in $\mathrm{ppbvhr}^{-1}$ ) are shown for the crown layer in Fig. 11a, and for the understory layer in Fig. 11b. From Fig. 11a it can be inferred that changes in the crown layer $\mathrm{NO}_{\mathrm{x}}$ mixing ratio are dominated by daytime downward turbulent transport into the canopy (shown as positive turbulence tendency). This downward transport compensates for chemical destruction and dry deposition. Figure $11 \mathrm{~b}$ also shows the contribution from soil emission, which provides a constant but relatively minor contribution in the overall net tendency. This confirms the low sensitivity of $\mathrm{NO}_{\mathrm{x}}$ at UMBS to the soil emission source. It is interesting to see that the net tendency after sunrise appears to be controlled 
(a)

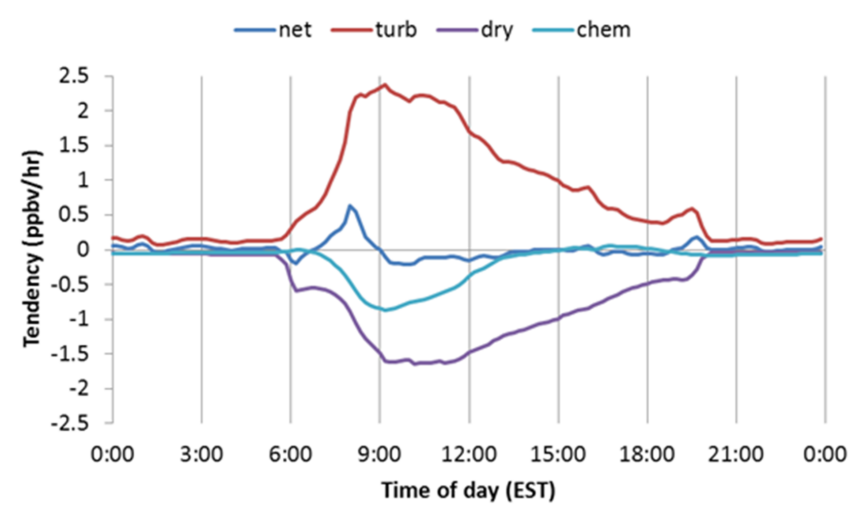

(b)

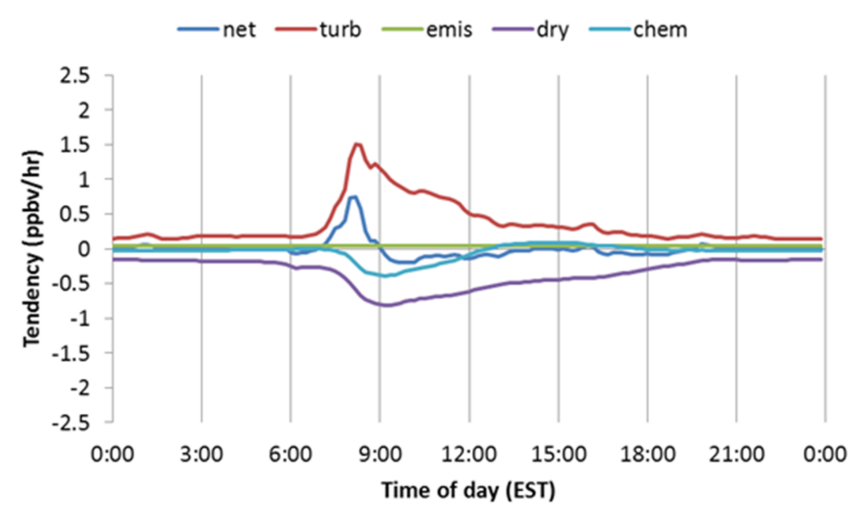

Fig. 11. Simulated August mean diurnal cycle in $\mathrm{NO}_{\mathrm{x}}$ process tendencies $\left(\mathrm{ppbvh}^{-1}\right.$ ) of emissions (red solid line), dry deposition (green long-dashed line), chemistry (blue short-dashed line), turbulent transport (maroon dashed line), and the net tendency (black solid line) (a) in the crown layer and (b) in the understory layer.

primarily by turbulent transport and dry deposition (Fig. 11). Meanwhile, the chemistry becomes a relevant sink $\sim 1.5 \mathrm{~h}$ after sunrise. The $\mathrm{SCM}$ calculates $\mathrm{NO}_{\mathrm{x}}$ dry deposition in the multi-layer canopy model from the leaf uptake resistance. This leaf uptake resistance includes non-stomatal and stomatal resistances, and it is calculated from radiation and moisture status in series with an assumed mesophyll resistance. In the default setup of the $\mathrm{SCM}$, the $\mathrm{NO}_{2}$ mesophyll resistance has a value such that the $\mathrm{NO}_{2}$ dry deposition to vegetation is $\sim 2 / 3$ the $\mathrm{O}_{3}$ dry deposition velocity, while NO leaf uptake is negligible (Ganzeveld and Lelieveld, 1995).

However, studies have shown that there exists a $\mathrm{NO}_{2}$ compensation point defined as the ambient $\mathrm{NO}_{2}$ mixing ratio at which the net exchange between a plant and the atmosphere is zero (e.g. Rondon et al., 1993; Rondon and Granat, 1994; Lerdau et al., 2000; Ganzeveld et al., 2002b; ChaparroSuarez et al., 2011). The $\mathrm{NO}_{2}$ compensation point can be viewed as a dynamic process. The canopy foliage can become a source or a sink depending on the ambient $\mathrm{NO}_{2}$ mixing ratio. This contrasts the foliage emission via nitrate pho-
$\mathrm{NO}_{\mathrm{x}}$ tendency with $\mathrm{NO}_{2}$ comp. $=1 \mathrm{ppbv}$, Crown layer

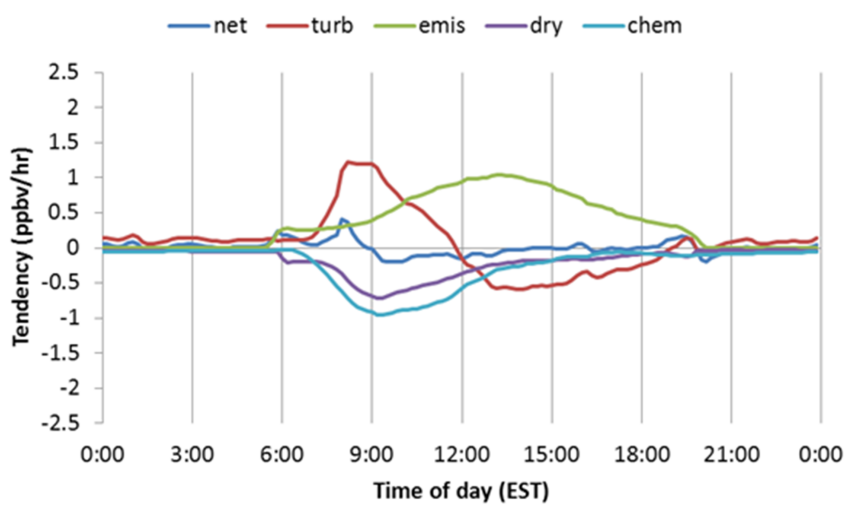

Fig. 12. Similar to Fig. 11a but showing the simulated August mean diurnal cycle in $\mathrm{NO}_{\mathrm{x}}$ process tendencies $\left(\mathrm{ppbvh}^{-1}\right)$ for the crown layer for an assumed $\mathrm{NO}_{2}$ compensation point of $1 \mathrm{ppbv}$.

tolysis, described in Sect. 5.2.2, which always functions as a source term (i.e. always resulting in a positive $\mathrm{NO}_{\mathrm{x}}$ flux). The $\mathrm{NO}_{2}$ gas exchange is a pure physical process, solely driven by ambient air mixing ratio levels. The compensation point mechanism was added on top of the foliage emission flux in these simulations.

A leaf-scale $\mathrm{NO}_{2}$ compensation point of $1 \mathrm{ppbv}$ was used in the simulation. This compensation point value was selected after conducting a sensitivity analysis (not shown) aiming to reproduce the observed trace gas levels throughout the day. With inclusion of this $\mathrm{NO}_{2}$ compensation point in the SCM, a relatively large $\mathrm{NO}_{\mathrm{x}}$ foliage emissions flux, exceeding the dry deposition term, was simulated (Fig. 12). Having this compensation point reverses the net tendency at $\sim 06: 00$ EST from a negative (see Fig. 11a) to a positive tendency (Fig. 12). Comparing Fig. 11a and Fig. 12, one would expect the turbulence tendency to be the same for both simulations. However, inclusion of a $\mathrm{NO}_{2}$ compensation point changes the sources and sinks; consequently, this changes the mixing ratios in the simulation. Therefore, the turbulent transport tendency (along with the concentration gradients and fluxes) will change accordingly, but the turbulent transport term, derived from the eddy diffusivity, in the SCM remained the same for the two cases. The simulated increases in atmospheric $\mathrm{NO}_{\mathrm{x}}$ and $\mathrm{NO}$ mixing ratios associated with this 1 ppbv $\mathrm{NO}_{2}$ compensation point is illustrated in Fig. 13. First of all, there is an improved simulation of absolute mixing ratios with maximum increases in $\mathrm{NO}_{\mathrm{x}}$ of $\sim 0.3 \mathrm{ppbv}$ and in $\mathrm{NO}$ of $\sim 0.05 \mathrm{ppbv}$ in the crown layer (Fig. 13c). Moreover, the better match in the timing of the $\mathrm{NO}_{\mathrm{x}}$ and $\mathrm{NO}$ maxima associated with these changes in leaf-level $\mathrm{NO}_{2}$ exchange (i.e. the $\mathrm{NO}_{2}$ compensation point) points towards this effect having a possible important contribution to the above canopy morning NO maximum.

At this time, there are no leaf-level experimental data available from this site to further substantiate the assumption 

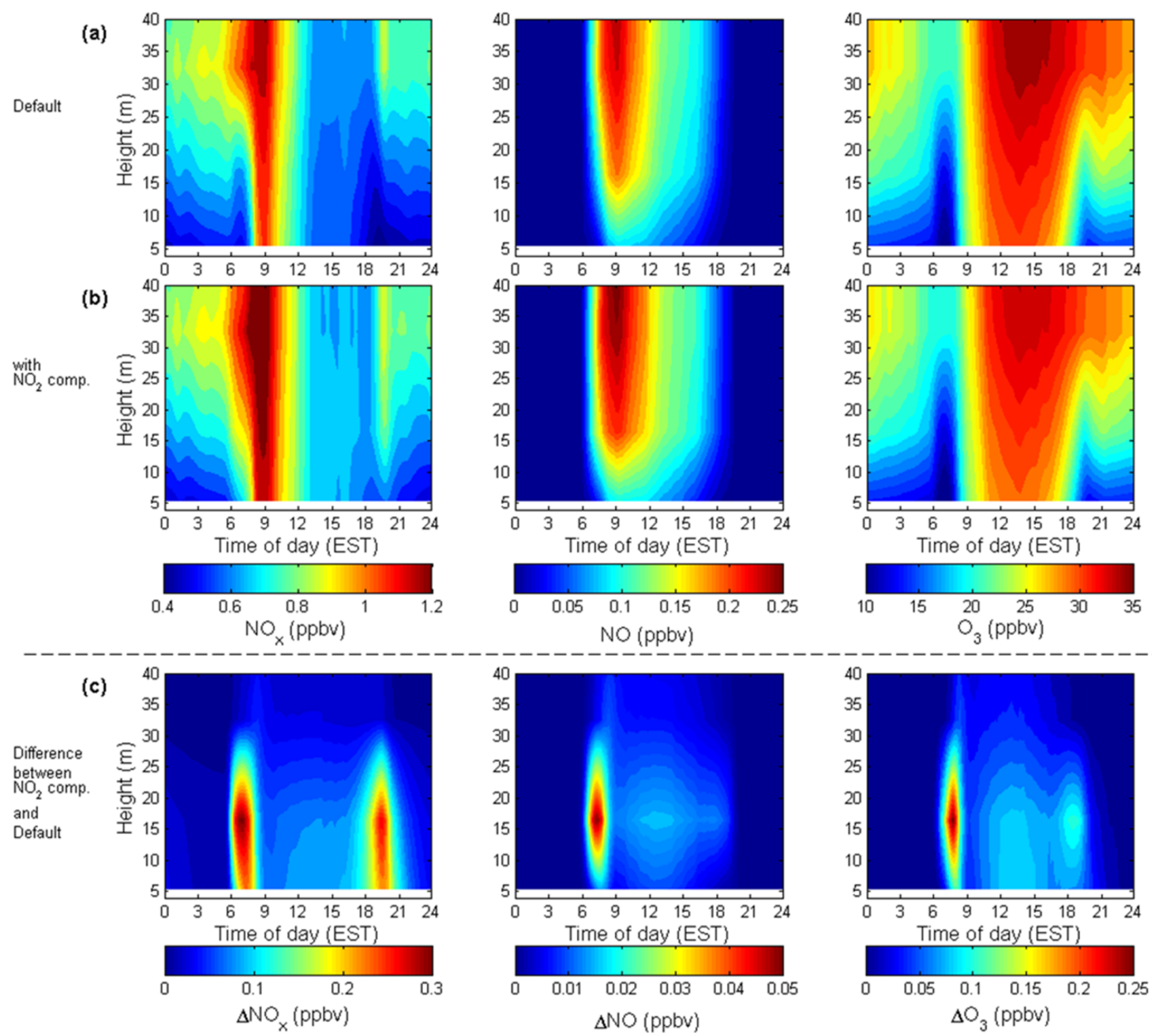

Fig. 13. Simulated August diurnal vertical profiles of $\mathrm{NO}_{\mathrm{x}}, \mathrm{NO}$, and $\mathrm{O}_{3}$ mixing ratios using (a) default parameters and (b) parameters with 1 ppbv $\mathrm{NO}_{2}$ compensation point. (c) The difference between simulation considering $\mathrm{NO}_{2}$ compensation point and the default.

that $\mathrm{NO}_{2}$ compensation point might play an important role in the dynamics of $\mathrm{NO}_{\mathrm{x}}$ at UMBS. However, after demonstrating the significant changes in absolute mixing ratios as well as temporal variability in $\mathrm{NO}_{\mathrm{x}}$, studies of the role of this foliage source of $\mathrm{NO}_{\mathrm{x}}$, warrant further investigation.

\subsection{Synthesis}

Based on our air mass transport analysis, we conclude that advection and entrainment of polluted air masses in addition to local scale atmosphere-biosphere exchanges play an integral role in the observed $\mathrm{NO}_{\mathrm{x}}$ dynamics at UMBS. Advection of $\mathrm{NO}_{\mathrm{x}}$ and $\mathrm{O}_{3}$ in the model was achieved by nudging the model layer above the canopy towards observation. Nudging the model allows us to assess the effects that local processes and non-local sources of pollution have on the temporal variability in $\mathrm{NO}_{\mathrm{x}}$ and $\mathrm{O}_{3}$ within and below the canopy under observed conditions. As such, our study - including the presented model analysis - adds to that by Alaghmand et al. (2011), who analyzed the relative contributions of in-canopy air versus the supply of $\mathrm{NO}_{\mathrm{x}}$ and other pollutants through advection and entrainment of residual layer air masses at UMBS solely based on observations.

The $3 \mathrm{~h}$ lag in the NO maximum after sunrise suggests that this maximum could be associated (1) with entrainment of polluted air masses higher up in the residual layer or (2) with advection of pollution from an anthropogenic source area at an upwind distance resembling a $3 \mathrm{~h}$ transport time. $\mathrm{Ob}-$ served vertical gradients and meteorological data imply mixing ratios in the understory layer are depleted by chemical reaction and deposition and replenished by downward mixing of elevated mixing ratios from above the canopy. Alaghmand et al. (2011) suggested that downward mixing of localized polluted air masses did not contribute to the morning $\mathrm{NO}_{\mathrm{x}}$ maximum. Rather, they proposed that long-range transport of aged polluted air masses explain the observed $\mathrm{NO}_{\mathrm{x}}$ peak. In cases where the air mass did not flow through major sources of $\mathrm{NO}_{\mathrm{x}}$, they attributed the morning $\mathrm{NO}_{\mathrm{x}}$ maximum to local soil $\mathrm{NO}_{\mathrm{x}}$ emissions. Alaghmand et al. (2011) found that in the early morning hours (hours prior to $06: 00 \mathrm{EST}$ ) $\sim 57 \%$ 
of the time, $\mathrm{NO}_{\mathrm{x}}$ mixing ratios were greater below than above canopy. Thus, they postulated that there is sufficient accumulation of $\mathrm{NO}_{\mathrm{x}}$ below canopy and if this $\mathrm{NO}_{\mathrm{x}}$ was to mix upward with the breakdown of the nocturnal boundary layer, it would contribute to the observed $\mathrm{NO}_{\mathrm{x}}$ maximum at sunrise. However, our observations and simulations showed little or no accumulation of NO in the understory layer, thus providing no evidence that soil $\mathrm{NO}$ emissions could influence the morning $\mathrm{NO}_{\mathrm{x}}$ maximum.

Munger et al. (1996) showed that $\mathrm{HNO}_{3}$ could mix into the canopy layer at sunrise with the breakdown of the nocturnal boundary layer, but efficient deposition of total oxidized nitrogen $\left(\mathrm{NO}_{\mathrm{y}}\right)$ would prevent $\mathrm{HNO}_{3}$ to accumulate in the understory layer. If there was a sufficient amount of $\mathrm{HNO}_{3}$ (or HONO) present on the surface of the canopy leaves, then photolysis upon sunrise could account for some of the increase in $\mathrm{NO}_{\mathrm{x}}$ mixing ratios during that time. Our simulations showed that foliage emissions of $\mathrm{NO}_{\mathrm{x}}$ via nitrate photolysis alone could not explain the observed $\mathrm{NO}_{\mathrm{x}}$ maximum in the morning. In fact, it appears that the diurnal behavior is not properly represented including this foliage $\mathrm{NO}_{\mathrm{x}}$ source from nitrate photolysis. However, when considering the $\mathrm{NO}_{2}$ compensation point at the leaf-scale of the canopy, our simulated results were closer to the observed, suggesting that the $\mathrm{NO}_{2}$ compensation point mechanism may be important in explaining the dynamics of $\mathrm{NO}_{\mathrm{x}}$ at UMBS.

The below-to-above canopy $\mathrm{O}_{3}$ dynamics in August reflects the combined role of in-canopy and boundary layer photochemistry and turbulent transport resulting in entrainment of free tropospheric air masses enhanced in $\mathrm{O}_{3}$ compensating for canopy deposition. During the night, $\mathrm{O}_{3}$ titration through its reaction with $\mathrm{NO}$ reduces below canopy $\mathrm{O}_{3}$ levels. However, the observed NO levels below canopy were generally about two orders of magnitude smaller compared to $\mathrm{O}_{3}$ implying that other sinks, e.g., ozonolysis of very reactive BVOCs (Kurpius and Goldstein, 2003), and dry deposition likely contribute to the apparent significant ozone sink in the understory. Bryan et al. (2012) also conducted a model study for this site and concluded that deposition was the primary sink for ozone in the canopy layer.

The simulation of dry deposition in our model is based on the selected fixed cuticular, soil and other substrate resistances according to Ganzeveld and Lelieveld (1995). Recent studies (e.g. Zhang et al., 2002; Altimir et al., 2004, 2006) have shown a potentially important role of non-stomatal uptake of $\mathrm{O}_{3}$ as a function of moisture conditions. To investigate the potential impact of such an enhanced removal by wet surfaces, we conducted an additional simulation in which we used the relative humidity $(\mathrm{RH})$ of the simulated surface layer as a proxy for canopy wetness (Altimir et al., 2006) (note that the model actually calculates the wet skin fraction, i.e., the fraction of vegetation that is wetted by dewfall and rain interception). We introduced a reduced cuticular resistance scaled between the default maximum resistance of $10^{5} \mathrm{~s} \mathrm{~m}^{-1}$ for a $\mathrm{RH}<70 \%$ and an assumed leaf-scale min- imum cuticular resistance of $1500 \mathrm{sm}^{-1}$ for a $\mathrm{RH}>95 \%$; in between a RH of 70-95\%, a linear scaling between the minimum and maximum resistance was applied. Selection of the minimum cuticular resistance is based on the reported canopy-scale $V_{d_{\mathrm{O}_{3}}}$ between 0.1 and $0.3 \mathrm{~cm} \mathrm{~s}^{-1}$ (Altimir et al., 2006, and references therein), resembling a canopy uptake resistance on the order of $500 \mathrm{sm}^{-1}$, and an LAI for this site on the order of $3-3.5 \mathrm{~m}^{2} \mathrm{~m}^{-2}$. Applying this substantially smaller non-stomatal uptake resistance as a function of $\mathrm{RH}$ resulted in simulated canopy $\mathrm{O}_{3}$ mixing ratios, that were up to $\sim 13 \mathrm{ppbv}$ smaller compared to the observed mixing ratios during nocturnal conditions. This indicates that this enhanced $\mathrm{O}_{3}$ removal mechanism is not a good representation for this site. However, it is known that non-stomatal ozone conductance represents over half of the total ozone flux at this site (Hogg et al., 2007). It is uncertain what drives the non-stomatal uptake of ozone. Kurpius and Goldstein (2003) suggested that this would be driven by temperature dependence in BVOC emissions in which ozone scavenging BVOCs would remove the ozone. In any case, our measurements do not allow us to partition between stomatal and non-stomatal uptake, and determining the drivers of the nonstomatal uptake is beyond the scope of this study.

Differences between the daytime August and November $\mathrm{O}_{3}$ mixing ratios could reflect the combined effect of different boundary layer dynamics (see Fig. 3), with a reduced entrainment of free troposphere air masses enriched in $\mathrm{O}_{3}$ in November compared to August. A reduced photochemistry in November is partly compensated by a reduced November $\mathrm{O}_{3}$ sink associated with a decrease in dry deposition.

In summary, the observed morning NO maximum appears to be caused by the photolysis of $\mathrm{NO}_{2}$ and leaf-level bidirectional exchanges of $\mathrm{NO}_{2}$ may contribute to the observed $\mathrm{NO}_{\mathrm{x}}$ dynamics. $\mathrm{NO}_{2}$ arises primarily from anthropogenic sources, and it is transported into the UMBS canopy by advection and entrainment.

\section{Summary and conclusions}

The dynamical behavior in $\mathrm{NO}_{\mathrm{x}}$ and $\mathrm{O}_{3}$ at a deciduous forest site at UMBS was investigated. We observed consistent occurrences of $\mathrm{NO}$ and $\mathrm{NO}_{\mathrm{x}, \mathrm{MO}}$ diurnal maxima above the canopy during the five-month measurement period from midsummer to late-fall. These occurrences continued after leaf fall, which implies that the observed diurnal maxima of $\mathrm{NO}$ and $\mathrm{NO}_{\mathrm{x}, \mathrm{MO}}$ are not controlled exclusively by biochemical processes in the canopy, but they are influenced also by processes not linked to the canopy. To determine the possible controls on the observed $\mathrm{NO}$ and $\mathrm{NO}_{\mathrm{x}, \mathrm{MO}}$ diurnal maxima, we combined concentration gradient and micrometeorological measurements with a canopy-boundary layer exchange model for a detailed analysis of the role of local sources and sinks (i.e. biogenic emissions, dry deposition, and chemistry) and turbulent transport versus the role of advection. 
According to our data analyses, the morning NO maximum at UMBS is associated with the increase in solar radiation after sunrise and most likely due to the photolysis of $\mathrm{NO}_{2, \mathrm{MO}}$. The model simulations indicate that soil $\mathrm{NO}$ emissions are not sufficient to explain the morning $\mathrm{NO}_{\mathrm{x}, \mathrm{MO}}$ peak concentrations. Also, sensitivity analyses with the SCM showed that foliage $\mathrm{NO}_{\mathrm{x}}$ emissions via nitrate photolysis do not appear to explain the observed morning $\mathrm{NO}_{\mathrm{x}, \mathrm{MO}}$ (and NO) maxima above the canopy as these processes yielded a misrepresentation of the observed diurnal variability in $\mathrm{NO}_{\mathrm{x}, \mathrm{MO}}$. Instead, the SCM analyses suggest that a leaf-level $\mathrm{NO}_{2}$ compensation point seems to play a role in the observed $\mathrm{NO}$ and $\mathrm{NO}_{\mathrm{x}, \mathrm{MO}}$ dynamics.

Observed and simulated $\mathrm{NO}_{\mathrm{x}}$ data indicate that the morning $\mathrm{NO}_{\mathrm{x}, \mathrm{MO}}$ maximum is associated with local and non-local transport events. The sensitivity analysis of the SCM and the analysis of air mass advection suggest that despite UMBS being located in a relatively remote area far from major urban sites, most of the $\mathrm{NO}_{\mathrm{x}, \mathrm{MO}}$ seen at UMBS is of anthropogenic origin and that its impact is significant on the chemistry observed at the site.

To understand the dynamics of $\mathrm{NO}_{\mathrm{x}}$ at UMBS, leaf-scale processes should be considered in addition to large scale advection, boundary layer dynamics, and entrainment. Therefore, more studies on leaf-scale processes and their effect on the biosphere-atmosphere exchange are needed for further evaluation of this question.

\section{Supplementary material related to this article is available online at: http://www.atmos-chem-phys.net/13/ 7301/2013/acp-13-7301-2013-supplement.zip.}

Acknowledgements. Thanks are due to S. Garrity for assistance with the experimental setup on the AmeriFlux tower and to K. Mauer for providing the AmeriFlux turbulence data. B. Seok and this research were sponsored through the NSF-IGERT Biosphere-Atmosphere Research and Training (BART) Fellowship administrated by the University of Michigan (NSF award \#0504552). Work on this research was also supported by funding from NSF AGS award \#0904139 and NSF Niwot Ridge Long Term Ecological Research (NWT-LTER) program (DEB-0423662). L. Ganzeveld acknowledges support by the EU 7th Framework project ECLAIRE (Effects of Climate Change on Air Pollution and Response Strategies for European Ecosystems).

Edited by: A. Hofzumahaus

\section{References}

Alaghmand, M., Shepson, P. B., Starn, T. K., Jobson, B. T., Wallace, H. W., Carroll, M. A., Bertman, S. B., Lamb, B., Edburg, S. L., Zhou, X., Apel, E., Riemer, D., Stevens, P., and Keutsch, F.: The Morning $\mathrm{NO}_{\mathrm{x}}$ maximum in the forest atmosphere boundary layer, Atmos. Chem. Phys. Discuss., 11, 2925129282, doi:10.5194/acpd-11-29251-2011, 2011.
Altimir, N., Tuovinen, J.-P., Vesala, T., Kulmala, M., and Hari, P.: Measurements of ozone removal by Scots pine shoots: calibration of a stomatal uptake model including the non-stomatal component, Atmos. Environ., 38, 2387-2398, doi:10.1016/j.atmosenv.2003.09.077, 2004.

Altimir, N., Kolari, P., Tuovinen, J.-P., Vesala, T., Bäck, J., Suni, T., Kulmala, M., and Hari, P.: Foliage surface ozone deposition: a role for surface moisture?, Biogeosciences, 3, 209-228, doi:10.5194/bg-3-209-2006, 2006.

Andreae, M. O., Artaxo, P., Brandao, C., Carswell, F. E., Ciccioli, P., da Costa, A. L., Culf, A. D., Esteves, J. L., Gash, J. H. C., Grace, J., Kabat, P., Lelieveld, J., Malhi, Y., Manzi, A. O., Meixner, F. X., Nobre, A. D., Nobre, C., Ruivo, M. d. L. P., Silva-Dias, M. A., Stefani, P., Valentini, R., von Jouanne, J., and Waterloo, M. J.: Biogeochemical cycling of carbon, water, energy, trace gases, and aerosols in Amazonia: the LBAEUSTACH experiments, J. Geophys. Res.-Atmos., 107, 8066, doi:10.1029/2001JD000524, 2002.

Atkinson, R., Baulch, D. L., Cox, R. A., Crowley, J. N., Hampson, R. F., Hynes, R. G., Jenkin, M. E., Rossi, M. J., and Troe, J.: Evaluated kinetic and photochemical data for atmospheric chemistry: Volume $\mathrm{I}-$ gas phase reactions of $\mathrm{O}_{\mathrm{X}}, \mathrm{HO}_{\mathrm{x}}, \mathrm{NO}_{\mathrm{x}}$ and $\mathrm{SO}_{\mathrm{x}}$ species, Atmos. Chem. Phys., 4, 1461-1738, doi:10.5194/acp-41461-2004, 2004.

Bakwin, P. S., Wofsy, S. C., Fan, S. M., Keller, M., Trumbore, S. E., and Dacosta, J. M.: Emission of nitric-oxide (NO) from tropical forest soils and exchange of NO between the forest canopy and atmospheric boundary-layers, J. Geophys. Res.-Atmos., 95, 16755-16764, 1990.

Bakwin, P. S., Jacob, D. J., Wofsy, S. C., Munger, J. W., Daube, B. C., Bradshaw, J. D., Sandholm, S. T., Talbot, R. W., Singh, H. B., Gregory, G. L., and Blake, D. R.: Reactive nitrogenoxides and ozone above a taiga, J. Geophys. Res.-Atmos., 99, 1927-1936, 1994.

Brodin, M., Helmig, D., and Oltmans, S.: Seasonal ozone behavior along an elevation gradient in the Colorado Front Range Mountains, Atmos. Environ., 44, 5305-5315, doi:10.1016/j.atmosenv.2010.06.033, 2010.

Bryan, A. M., Bertman, S. B., Carroll, M. A., Dusanter, S., Edwards, G. D., Forkel, R., Griffith, S., Guenther, A. B., Hansen, R. F., Helmig, D., Jobson, B. T., Keutsch, F. N., Lefer, B. L., Pressley, S. N., Shepson, P. B., Stevens, P. S., and Steiner, A. L.: In-canopy gas-phase chemistry during CABINEX 2009: sensitivity of a 1-D canopy model to vertical mixing and isoprene chemistry, Atmos. Chem. Phys., 12, 8829-8849, doi:10.5194/acp-12-8829-2012, 2012.

Carleton, L., Carrol, M. A., and Hogg, A.: NO flux from soils surrounding PROPHET tower at UMB S.: Deep Blue at the University of Michigan, available at: http://hdl.handle.net/2027.42/ 54978 (last accessed 29 April 2011), 2003.

Carroll, M. A. and Thompson, A. M.: $\mathrm{NO}_{\mathrm{x}}$ in the non-urban troposphere, in: Progress and Problems in Atmospheric Chemistry, vol. 3, edited by: Barker, J. R., World Scientific, River Edge, NJ, USA, 198-226, 1995.

Carroll, M. A., Bertman, S. B., and Shepson, P. B.: Overview of the program for research on oxidants: photochemistry, emissions, and transport (PROPHET) summer 1998 measurements intensive, J. Geophys. Res.-Atmos., 106, 24275-24288, 2001. 
Chaparro-Suarez, I. G., Meixner, F. X., and Kesselmeier, J.: Nitrogen dioxide $\left(\mathrm{NO}_{2}\right)$ uptake by vegetation controlled by atmospheric concentrations and plant stomatal aperture, Atmos. Environ., 45, 5742-5750, doi:10.1016/j.atmosenv.2011.07.021, 2011.

Cooper, O. R., Moody, J. L., Thornberry, T. D., Town, M. S., and Carroll, M. A.: PROPHET 1998 meteorological overview and air-mass classification, J. Geophys. Res.-Atmos., 106, 2428924299, 2001.

Crutzen, P. J.: Influence of nitrogen oxides on atmospheric ozone content, Q. J. Roy. Meteor. Soc., 96, 320-325, 1970.

Crutzen, P. J. and Lelieveld, J.: Human impacts on atmospheric chemisty, Annu. Rev. Earth Pl. Sc., 29, 17-45, 2001.

Demerjian, K. L.: A review of national monitoring networks in North America, Atmos. Environ., 34, 1861-1884, 2000.

Farmer, D. K. and Cohen, R. C.: Observations of $\mathrm{HNO}_{3}, \Sigma \mathrm{AN}$, $\Sigma \mathrm{PN}$ and $\mathrm{NO}_{2}$ fluxes: evidence for rapid $\mathrm{HO}_{\mathrm{x}}$ chemistry within a pine forest canopy, Atmos. Chem. Phys., 8, 3899-3917, doi:10.5194/acp-8-3899-2008, 2008.

Fuchs, H., Holland, F., and Hofzumahaus, A.: Measurement of tropospheric $\mathrm{RO}_{2}$ and $\mathrm{HO}_{2}$ radicals by a laser-induced fluorescence instrument, Rev. Sci. Instrum., 79, 084104, doi:10.1063/1.2968712, 2008.

Ganzeveld, L. and Lelieveld, J.: Dry deposition parameterization in a chemistry general-circulation model and its influence on the distribution of reactive trace gases, J. Geophys. Res.-Atmos., 100, 20999-21012, 1995.

Ganzeveld, L. N., Lelieveld, J., Dentener, F. J., Krol, M. C., and Roelofts, G. J.: Atmosphere-biosphere trace gas exchanges simulated with a single-column model, J. Geophys. Res.-Atmos., 107, 4297, doi:10.1029/2001JD000684, 2002a.

Ganzeveld, L. N., Lelieveld, J., Dentener, F. J., Krol, M. C., Bouwman, A. F., and Roelofs, G. J.: Global soil-biogenic $\mathrm{NO}_{\mathrm{x}}$ emissions and the role of canopy processes, J. Geophys. Res.-Atmos., 107, 4298, doi:10.1029/2001JD001289, 2002b.

Ganzeveld, L., Klemm, O., Rappenglueck, B., and Valverde-Canossa, J.: Evaluation of meteorological parameters over a coniferous forest in a single-column chemistry-climate model, Atmos. Environ., 40, 21-27, doi:10.1016/j.atmosenv.2006.01.061, 2006.

Ganzeveld, L., Eerdekens, G., Feig, G., Fischer, H., Harder, H., Königstedt, R., Kubistin, D., Martinez, M., Meixner, F. X., Scheeren, H. A., Sinha, V., Taraborrelli, D., Williams, J., VilàGuerau de Arellano, J., and Lelieveld, J.: Surface and boundary layer exchanges of volatile organic compounds, nitrogen oxides and ozone during the GABRIEL campaign, Atmos. Chem. Phys., 8, 6223-6243, doi:10.5194/acp-8-6223-2008, 2008.

Gilge, S., Plass-Dulmer, C., Wyrauch, D., Rohrer, F.: ACTRIS-NOx Team: QA/QC of European $\mathrm{NO}_{\mathrm{x}}$ measurements by round robin and side by side experiment at the Meteorological Observatory Hohenpeissenberg in the framework of ACTRIS, Geophys. Res. Abstracts, 15, EGU2013-8403, 2013.

Gough, C. M., Vogel, C. S., Harrold, K. H., George, K., and Curtis, P. S.: The legacy of harvest and fire on ecosystem carbon storage in a north temperate forest, Glob. Change Biol., 13, 19351949, doi:10.1111/j.1365-2486.2007.01406.x, 2007.

Grunhage, L., Dammgen, U., Erisman, J. W., Luttich, M., Hanewald, K., Jager, H. J., Freitag, K., Baltrusch, M., and Liebl, K.: Atmospheric nitrogen dynamics in Hesse, Germany: the challenge and its potential solution, Landbauforsch. Volk.,
52, 219-228, 2002.

Guenther, A., Hewitt, C. N., Erickson, D., Fall, R., Geron, C., Graedel, T., Harley, P., Klinger, L., Lerdau, M., McKay, W. A., Pierce, T., Scholes, B., Steinbrecher, R., Tallamraju, R., Taylor, J., and Zimmerman P.: A global-model of natural volatile organic-compound emissions, J. Geophys. Res.-Atmos., 100, 8873-8892, doi:10.1029/94JD02950, 1995.

Guenther, A., Karl, T., Harley, P., Wiedinmyer, C., Palmer, P. I., and Geron, C.: Estimates of global terrestrial isoprene emissions using MEGAN (Model of Emissions of Gases and Aerosols from Nature), Atmos. Chem. Phys., 6, 3181-3210, doi:10.5194/acp-63181-2006, 2006.

Hanson, P. J. and Lindberg, S. E.: Dry deposition of reactive nitrogen-compounds - a review of leaf, canopy and non-foliar measurements, Atmos. Environ., 25, 1615-1634, 1991.

Hauglustaine, D., Emmons, L., Newchurch, M., Brasseur, G., Takao, T., Matsubara, K., Johnson, J., Ridley, B., Stith, J., and Dye, J.: On the role of lightning $\mathrm{NO}_{\mathrm{x}}$ in the formation of tropospheric ozone plumes: a global model perspective, J. Atmos. Chem., 38, 277-294, 2001.

Hogg, A., Uddling, J., Ellsworth, D., Carroll, M. A., Pressley, S., Lamb, B., and Vogel, C.: Stomatal and non-stomatal fluxes of ozone to a northern mixed hardwood forest, Tellus B, 59, 514525, doi:10.1111/j.1600-0889.2007.00269.x, 2007.

Hollinger, D. Y., Ollinger, S. V., Richardson, A. D., Meyers, T. P., Dail, D. B., Martin, M. E., Scott, N. A., Arkebauer, T. J., Baldocchi, D. D., Clark, K. L., Curtis, P. S., Davis, K. J., Desai, A. R., Dragoni, D., Goulden, M. L., Gu, L., Katul, G. G., Pallardy, S. G., Paw U, K. T., Schmid, H. P., Stoy, P. C., Suyker, A. E., and Verma, S. B.: Albedo estimates for land surface models and support for a new paradigm based on foliage nitrogen concentration, Glob. Change Biol., 16, 696-710, doi:10.1111/j.13652486.2009.02028.x, 2010.

Jacob, D. J.: Heterogeneous chemistry and tropospheric ozone, Atmos. Environ., 34, 2131-2159, 2000.

Kurpius, M. R. and Goldstein, A. H.: Gas-phase chemistry dominates $\mathrm{O}_{3}$ loss to a forest, implying a source of aerosols and hydroxyl radicals to the atmosphere, Geophys. Res. Lett., 30, 1371, doi:10.1029/2002GL016785, 2003.

Lerdau, M. T., Munger, L. J., and Jacob, D. J.: The $\mathrm{NO}_{2}$ flux conundrum, Science, 289, 2291-2293, doi:10.1126/science.289.5488.2291, 2000.

Mosier, A. R., Bleken, M. A., Chaiwanakupt, P., Ellis, E. C., Freney, J. R., Howarth, R. B., Matson, P. A., Minami, K., Naylor, R., Weeks, K. N., and Zhu, Z. L.: Policy implications of human-accelerated nitrogen cycling, Biogeochemistry, 52, 281320, 2001.

Munger, J. W., Wofsy, S. C., Bakwin, P. S., Fan, S. M., Goulden, M. L., Daube, B. C., Goldstein, A. H., Moore, K. E., and Fitzjarrald, D. R.: Atmospheric deposition of reactive nitrogen oxides and ozone in a temperate deciduous forest and a subarctic woodland, 1: measurements and mechanisms, J. Geophys. Res.-Atmos., 101, 12639-12657, 1996.

Nave, L. E., Gough, C. M., Maurer, K. D., Bohrer, G., Hardiman, B. S., Le Moine, J., Munoz, A. B., Nadelhoffer, K. J., Sparks, J. P., Strahm, B. D., Vogel, C. S., and Curtis, P. S.: Disturbance and the resilience of coupled carbon and nitrogen cycling in a north temperate forest, J. Geophys. Res., 116, G04016, doi:10.1029/2011JG001758, 2011. 
Ortega, J., Helmig, D., Guenther, A., Harley, P., Pressley, S., and Vogel, C.: Flux estimates and $\mathrm{OH}$ reaction potential of reactive biogenic volatile organic compounds (BVOCs) from a mixed northern hardwood forest, Atmos. Environ., 41, 5479-5495, doi:10.1016/j.atmosenv.2006.12.033, 2007.

Parrish, D. D., Buhr, M. P., Trainer, M., Norton, R. B., Shimshock, J. P., Fehsenfeld, F. C., Anlauf, K. G., Bottenheim, J. W., Tang, Y. Z., Wiebe, H. A., Roberts, J. M., Tanner, R. L., Newman, L., Bowersox, V. C., Olszyna, K. J., Bailey, E. M., Rodgers, M. O., Wang, T., Berresheim, H., Roychowdhury, U. K., and Demerjiani, K. L.: The total reactive oxidized nitrogen levels and the partitioning between the individual-species at 6 rural sites in Eastern North-America, J. Geophys. Res.-Atmos., 98, 2927-2939, doi:10.1029/92JD02384, 1993.

Pressley, S., Lamb, B., Westberg, H., Flaherty, J., Chen, J., and Vogel, C.: Long-term isoprene flux measurements above a northern hardwood forest, J. Geophys. Res.-Atmos., 110, D07301, doi:10.1029/2004JD005523, 2005.

Rondon, A. and Granat, L.: Studies on the dry deposition of $\mathrm{NO}_{2}$ to coniferous tree species at low $\mathrm{NO}_{2}$ concentrations, Tellus, 46, 339-352, 1994.

Rondon, A., Johansson, C., and Granat, L.: Dry deposition of nitrogen dioxide and ozone to coniferous forests, J. Geophys. Res., 98, 5159-5172, 1993.

Rummel, U., Ammann, C., Gut, A., Meixner, F. X., and Andreae, M. O.: Eddy covariance measurements of nitric oxide flux within an Amazonian rain forest, J. Geophys. Res.-Atmos., 107, 8050, doi:10.1029/2001JD000520, 2002.

Schmid, H. P., Su, H. B., Vogel, C. S., and Curtis, P. S.: Ecosystematmosphere exchange of carbon dioxide over a mixed hardwood forest in northern lower Michigan, J. Geophys. Res.-Atmos., 108, 4417, doi:10.1029/2002JD003011, 2003.

Spicer, C. W.: The distribution of oxidized nitrogen in urban air, Sci. Total Environ., 24, 183-192, 1982.

Steinbacher, M., Zellweger, C., Schwarzenbach, B., Bugmann, S., Buchmann, B., Ordonez, C., Prevot, A. S. H., and Hueglin, C.: Nitrogen oxide measurements at rural sites in Switzerland: bias of conventional measurement techniques, J. Geophys. Res.Atmos., 112, D11307, doi:10.1029/2006JD007971, 2007.
Thornberry, T., Carroll, M. A., Keeler, G. J., Sillman, S., Bertman, S. B., Pippin, M. R., Ostling, K., Grossenbacher, J. W., Shepson, P. B., Cooper, O. R., Moody, J. L., and Stockwell, W. R.: Observations of reactive oxidized nitrogen and speciation of $\mathrm{NO}_{y}$ during the PROPHET summer 1998 intensive, J. Geophys. Res.-Atmos., 106, 24359-24386, doi:10.1029/2000JD900760, 2001.

United States Department of Agriculture Forest Service: Strategy for the 90's for USDA Forest Service Research, Technical Report, United States Department of Agriculture, Washington, DC, USA, 1990.

United States Environmental Protection Agency: Clean Air Status and Trends Network (CASTNET) 2009 Annual Report, Annual Report, US Environmental Protection Agency, Washington, DC, USA, available at: http://epa.gov/castnet/javaweb/docs/ annual_report_2009.pdf (last access: 1 February 2011), 2009.

Vande Kopple, B.: UM Biological Station - Research Resources: Climatology, available at: http://sitemaker.umich.edu/ umbs/climatology (last access: 29 April 2011), 2011.

Yienger, J. J. and Levy, H.: Empirical-model of global soil-biogenic $\mathrm{NO}_{\mathrm{x}}$ emissions, J. Geophys. Res.-Atmos., 100, 11447-11464, 1995.

Zhang, L. M., Brook, J. R., and Vet, R.: On ozone dry deposition with emphasis on non-stomatal uptake and wet canopies, Atmos. Environ., 36, 4787-4799, 2002.

Zhou, X., Gao, H., He, Y., Huang, G., Bertman, S. B., Civerolo, K., and Schwab, J.: Nitric acid photolysis on surfaces in low- $\mathrm{NO}_{\mathrm{X}}$ environments: significant atmospheric implications, Geophys. Res. Lett., 30, 2217, doi:10.1029/2003GL018620, 2003.

Zhou, X. L., Zhang, N., TerAvest, M., Tang, D., Hou, J., Bertman, S., Alaghmand, M., Shepson, P. B., Carroll, M. A., Griffith, S., Dusanter, S., and Stevens, P. S.: Nitric acid photolysis on forest canopy surface as a source for tropospheric nitrous acid, Nat. Geosci., 4, 440-443, doi:10.1038/NGEO1164, 2011. 